\title{
The effect of grape juice dilution on oenological fermentation.
}

Jennifer Margaret Gardner, ${ }^{1,}$, Michelle Elisabeth Walker ${ }^{1 *}$, Paul Kenneth Boss, ${ }^{2,3}$ and Vladimir Jiranek $k^{1,3}$

${ }^{1}$ Department of Wine and Food Science, School of Agriculture, Food and Wine, The University of Adelaide, Waite Campus, Urrbrae, SA 5064, Australia;

${ }^{2}$ CSIRO, Agriculture and Food, Waite Campus, Urrbrae, SA 5064, Australia;

${ }^{3}$ Australian Research Council Training Centre for Innovative Wine Production, The University of Adelaide, Waite Campus, Urrbrae, SA 5064, Australia

${ }^{\S}$ Corresponding author

*These authors have contributed equally

Dr Jennifer Gardner

Department of Wine and Food Science

University of Adelaide

Urrbrae, SA 5064

Australia

Phone: +61 83130402

Email: jennie.gardner@adelaide.edu.au

Other author email addresses:

Vladimir Jiranek: vladimir.jiranek@adelaide.edu.au

Michelle Walker: michelle.walker@adelaide.edu.au

Paul Boss: paul.boss@csiro.au

\section{Running Title:}

The effect of grape juice dilution on fermentation 


\section{Author Declaration:}

All authors agree that this manuscript is original, has not been published before, and is not currently being considered for publication elsewhere.

We wish to confirm that there are no known competing financial interests or personal relationships that could have appeared to influence the work reported in this paper.

We confirm that the manuscript has been read and approved by all named authors, all have contributed significantly and that there are no other persons who satisfied the criteria for authorship but are not listed.

We further confirm that the order of authors listed in the manuscript has been approved by all of us.

We confirm that we have given due consideration to the protection of intellectual property associated with this work and that there are no impediments to publication, including the timing of publication, with respect to intellectual property. In so doing we confirm that we have followed the regulations of our institutions concerning intellectual property.

We understand that the Corresponding Author is the sole contact for the Editorial process (including Editorial Manager and direct communications with the office). She is responsible for communicating with the other authors about progress, submissions of revisions and final approval of proofs. We confirm that we have provided a current, correct email address, which is accessible by the Corresponding Author. 


\section{CRediT author statement}

Jennifer Gardner: Conceptualization, Methodology, Validation, Formal analysis, Investigation, Writing - Original Draft. Michelle Walker: Conceptualization, Methodology, Validation, Formal analysis, Investigation, Writing - Review \& Editing. Paul Boss: Methodology, Investigation, Writing - Review \& Editing. Vladimir Jiranek: Conceptualization, Resources, Writing - Review \& Editing, Supervision, Funding acquisition. 


\section{Highlights: Gardner et al. The effect of grape juice dilution on fermentation}

- Grape juice dilution shortened both alcoholic and malolactic fermentation

- In some conditions addition of commercial nutrient decreased fermentation duration

- In general wine volatiles decrease with grape juice dilution

- Isoamyl acetate can be decreased in wine by grape juice dilution 


\section{The effect of grape juice dilution on oenological fermentation}

3 Jennifer Margaret GARDNER ${ }^{1 *}$, Michelle Elizabeth WALKER ${ }^{1 *}$, Paul Kenneth BOSS ${ }^{2,3}$ and

4 Vladimir JIRANEK ${ }^{1,3}$

5

$6{ }^{1}$ Department of Wine Science, School of Agriculture, Food and Wine, The University of Adelaide,

7 Waite Campus, Urrbrae, SA 5064, Australia; ${ }^{2} \mathrm{CSIRO}$, Agriculture and Food, Waite Campus,

8 Urrbrae, SA 5064, Australia; ${ }^{3}$ Australian Research Council Training Centre for Innovative Wine

9 Production, The University of Adelaide, Waite Campus, Urrbrae, SA 5064, Australia

11 Corresponding author: Jennifer Gardner: jennie.gardner@adelaide.edu.au

12 Michelle Walker: michelle.walker@,adelaide.edu.au

13 Paul Boss: paul.boss@csiro.au

14 Vladimir Jiranek: vladimir.jiranek@adelaide.edu.au

$15 *$ These authors have contributed equally. 
Abstract

The impact of water addition to grape juice in winemaking, on both alcoholic and malolactic fermentation duration and outcome has been examined using commercial wine yeasts, Lalvin $\mathrm{EC} 1118^{\mathrm{TM}}$ and Lalvin $\mathrm{R} 2^{\mathrm{TM}}$ and malolactic bacteria Lalvin $\mathrm{VP} 41^{\mathrm{TM}}$. As expected, dilution with water did not impede fermentation, instead resulted in shortened duration, or in the case of malolactic fermentation enabled completion in these conditions. Addition of complex organic nutrient further shortened alcoholic fermentation by Lalvin $\mathrm{R} 2^{\mathrm{TM}}$ and in some conditions also reduced the duration of malolactic fermentation. In general, volatile compounds and some major yeast metabolites were present at lower concentrations at the end of fermentation where juices were diluted and the addition of organic complex nutrient also influenced the concentration of some compounds in wine. These findings are significant to commercial winemaking, highlighting that winemakers should consider potential impacts of juice dilution on processing efficiencies along with wine flavour and aroma.

Keywords: fermentation, dilution, yeast, nutrient, volatile compounds

\section{Introduction}

The addition of water pre-fermentation is legal and commonplace in many countries, including more recently, Australia. The wording of legislature around water additions varies between countries, for instance additions are allowed "to facilitate fermentation" (USA, Australia), " pre-

41 fermentation and not to below $13.5^{\circ}$ Bé" (Australia) or "where required on account of a specific technical necessity" (European Union). Fermentation difficulties can be encountered in high sugar musts where yeasts can fail to ferment all available sugars, leading to wines that are out of specification. High-sugar musts are becoming increasingly common since elevated daily average temperatures during ripening (Schultz, 2016) can lead to accelerated and uneven phenological 
development of grapes, resulting in vintage compaction and delay of harvest by winemakers waiting for "flavour ripeness". Market limitations also exist for higher alcohol wines, where higher taxes are incurred and some consumers are increasingly avoiding these in favour of wines with lower alcohol, suiting some modern flavour and healthier lifestyle choices. The addition of water to must prefermentation to combat the problems associated with high sugar musts is a simple and inexpensive procedure for which the practical logistics have been discussed (Cowey, 2017). Previous studies have examined the effect of juice dilution with water on final concentrations and sensory impacts of various compounds in wine (Harbertson, Mireles, Harwood, Weller, \& Ross, 2009; Petrie, Teng, Smith, \& Bindon, 2019; Schelezki, Antalick, Šuklje, \& Jeffery, 2020; Schelezki, Smith, Hranilovic, Bindon, \& Jeffery, 2018; Schelezki, Suklje, Boss, \& Jeffery, 2018; Teng, Petrie, Smith, \& Bindon, 2020). Authors report variable effects on wine, from an overall decrease in wine volatiles (Schelezki et al., 2020) to an increase to specific compounds (Schelezki, Suklje, et al., 2018), and minor to measurable decreases in colour, tannin and phenolics (Schelezki, Smith, et al., 2018; Teng et al., 2020). Some wines were also reported as generally not being reduced in sensorial complexity, in fact some dilutions maintain many of the fuller bodied and richer flavours of wine from undiluted juices (Petrie et al., 2019). In terms of grape derived compounds, presumably this reflects that changing the juice to solid ratio, or indeed simply providing more water, enables increased extraction. The variability in the reported effect of dilution inevitably arises due the complexities of variety, vintage and experimental differences, as reported by (Schelezki et al., 2020). Overall, authors suggest that impacts on wine of juice dilution pre-fermentation are surprisingly minor. Similarly it is hypothesised that these additions will not impede alcoholic and malolactic fermentation, however research has yet to specifically address this. We hypothesise that the addition of water to juice pre-fermentation will shorten fermentation time and effect the final concentration of some compounds in the final wine in proportion to the dilution. To test this, we analysed fermentation dynamics of two commercial wine yeast; Lalvin EC1118 ${ }^{\mathrm{TM}}$ (aromatically neutral) and Lalvin $\mathrm{R} 2^{\mathrm{TM}}$ (aromatic) over a range of juice dilutions (16 Bé juice diluted to 14.5, 13.5 and 12.5 
Bé, corresponding to water additions of 10.5, 17.2 and 24\%). Pressed juice from white grapes was chosen so as to avoid the complexities introduced when winemaking with skin contact is undertaken. Furthermore, studies addressing the impact of juice dilution on extraction of colour and phenolics in red wines fermented in the presence of skins have been recently reported (Schelezki et al., 2020; Teng et al., 2020). Nitrogen was ameliorated to be equal across all juices to ensure this was not impacting fermentation dynamics. Yeast nutrient $\left(\right.$ FERMAID $^{\circledR} \mathrm{O}$, an organic complex nutrient; Lallemand) was also added to examine if any negative effects (potentially due to the dilution of micronutrients), could be reduced. It is well known that many compounds (volatile and non-volatile) in wine change with the addition of nitrogenous compounds (Torrea, Fraile, Garde, \& Ancin, 2003; Bell \& Henschke, 2005), thus inclusion of this analysis allowed us to examine the combined effects of dilution and nutrient supplementation.

\section{Materials and methods}

\subsection{Strains and media}

Saccharomyces cerevisiae strains Lalvin $\mathrm{EC} 1118^{\mathrm{TM}}$ and Lalvin $\mathrm{R} 2^{\mathrm{TM}}$ (Lallemand, Canada) were chosen due to their common commercial use, variation in nutrient requirements and contribution to wine aroma (Lavin $\mathrm{EC} 1118^{\mathrm{TM}}$ regarded as neutral and Lalvin $\mathrm{R} 2^{\mathrm{TM}}$ as aromatic). Yeast were grown from single colonies in Yeast Peptone Dextrose (YPD) medium (1\% w/v yeast extract, $2 \% \mathrm{w} / \mathrm{v}$ bacteriological peptone, and $2 \% \mathrm{w} / \mathrm{v}$ glucose $)$ overnight at $28^{\circ} \mathrm{C}$ with shaking $(120 \mathrm{rpm})$. These cells were then inoculated at $2.5 \times 10^{6}$ cells $\mathrm{mL}^{-1}$ in diluted juice $(45 \%$, sterile $(0.22 \mu \mathrm{m}), 2018$ Viognier-Marsanne blend, 10\% YPD, 45\% water) and grown overnight. This culture was used to inoculate experimental fermentations.

Oenococcus oeni malolactic bacteria strain VP41 ${ }^{\mathrm{TM}}$ (Lallemand) was chosen as it is widely used in the Australian wine industry. VP41 (2.5g) was rehydrated from a commercial packet, according to the manufacturer's instructions and grown in $50 \mathrm{~mL}$ of MRSAJ (de Man-Rogosa-Sharp medium (Amyl Media) supplemented with 20\% ( $\mathrm{v} / \mathrm{v})$ apple juice and $0.1 \%$ cyclohexamide $(\mathrm{v} / \mathrm{v})$ ) for 4 days at 
$30{ }^{\circ} \mathrm{C}$ and $20 \% \mathrm{CO}_{2}$. The culture was centrifuged (10 min, $4600 \mathrm{xg}$ ), and the pellet was washed in phosphate buffered saline (PBS) and re-centrifuged. The cell pellet was washed with $50 \mathrm{~mL}$ Viognier-Marsanne juice (13.5 Bé, $0.22 \mu \mathrm{m})$, spun down and resuspended in $50 \mathrm{~mL}$ ViognierMarsanne juice. Light microscopy confirmed the culture as viable $O$. oeni. The culture was grown overnight at $30{ }^{\circ} \mathrm{C}$ and $20 \% \mathrm{CO}_{2}$ prior to inoculation at $1: 100(0.25 \mathrm{~mL})$ in the experimental fermentations. Culture viability was analysed using spot plating $(10 \mathrm{uL}$ of serially diluted cultures were grown on MRSAJ with 2\% agar, and colonies enumerated post growth).

A filter sterile $(0.22 \mu \mathrm{m}) 2018$ Viognier-Marsanne ( 75\% Viognier) blended juice was used for experimental fermentations (16 Bé, $\mathrm{pH} 3.2,3.13 \mathrm{~g} \mathrm{~L}^{-1}$ malic acid, 18:63 $\mathrm{mg} \mathrm{L}^{-1}$ free:total $\mathrm{SO}_{2}, 60$ $\mathrm{mg} \mathrm{L}^{-1}$ ammonia, $196 \mathrm{mg} \mathrm{L}^{-1}$ alpha amino nitrogen, $245 \mathrm{mg} \mathrm{L}^{-1}$ yeast assimilable nitrogen (YAN)). Juices were diluted with ultrapure water $(\mathrm{pH} 7.0)$ to $14.5,13.5$ and 12.5 Bé $(10.5,17.2$ and $24 \%$ water). Density after addition of water was calculated instead of measured as, based on experience, measurement at that stage is inaccurate. Nitrogen was also adjusted in diluted juices to $245 \mathrm{mg}$ YAN L $^{-1}$ with diammonium phosphate and complex organic nutrient (FERMAID ${ }^{\circledR}$ O, Lallemand) was added where indicated at either 0 (control), 200 or $400 \mathrm{mg} \mathrm{L}^{-1}$.

\subsection{Experimental fermentation}

Fermentations were conducted with a custom-made high throughput robotic platform 'Tee-bot v.2.0' built on an EVO freedom workdeck (Tecan, Männedorf, Switzerland) that can accommodate 384 discreet fermentations and sample automatically at programmable intervals. Fermentation vessels had custom-made airlocks that allowed sampling through a silicon septum and were mixed at inoculation and briefly before sampling with magnetic stir bars. Viognier-Marsanne juice was pressed from solids to alleviate the complexity of changing the juice:solid ratio by dilution in fermentations typically undertaken with most red wines. Temperature was regulated to $17{ }^{\circ} \mathrm{C}$ by a water bath that housed the fermentation flasks. $25 \mathrm{~mL}$ of juice (ameliorated with dilution or addition of FERMAID ${ }^{\circledR} \mathrm{O}$ ) was inoculated with $5 \times 10^{6}$ yeast cells $\mathrm{mL}^{-1}$ (either EC1118 ${ }^{\mathrm{TM}}$ or Lalvin $\mathrm{R}^{\mathrm{TM}}$ ). After 24 hours, experimental fermentations treated with lactic acid bacteria $(\mathrm{LAB}+)$ were inoculated 
123

with $0.25 \mathrm{~mL}$ of cultured VP41. Control (LAB-) fermentations had $0.25 \mathrm{~mL}$ sterile Viognier-

Marsanne juice added. Fermentations were performed in triplicate. This combination of treatments of yeast (Lalvin $\mathrm{EC} 1118^{\mathrm{TM}}$, Lalvin $\mathrm{R} 2^{\mathrm{TM}}$ or none), dilution $(16,14.5,13.5$ or 12.5 Bé), nutrient addition $\left(0,200\right.$ or $\left.400 \mathrm{mg} \mathrm{L}^{-1}\right)$ and LAB (+/-) resulted in 216 unique fermentations. During fermentation, sugars (glucose, fructose) and malic acid consumption were monitored using modified commercial enzymatic kits (Megazyme, Bray, Ireland) as described in (Walker et al., 2014) and (Jiang, Sumby, Sundstrom, Grbin, \& Jiranek, 2018).

\subsection{Determination of wine composition by HPLC and GC-MS.}

Major yeast metabolites, organic acids (malic, succinic, acetic), glucose, fructose, glycerol and ethanol were determined from terminal fermentation samples by HPLC according to (Lin, Boss, Walker, Sumby, Grbin, \& Jiranek, 2020).

Terminal fermentation samples were also analysed by solid phase micro-extraction (SPME)-GC/MS according to Hranilovic et al. (2018) with extraction and chromatographic condition as outlined by Boss and coworkers (2015). Samples of un-inoculated juices, subjected to the same experimental conditions were also analysed to decipher between juice and fermentation related volatiles. The concentrations of volatiles measured in unfermented juices were very low or below detection (data not shown).

\subsection{Statistical analysis}

Statistical analysis was undertaken with GraphPad Prism v 7.02 (GraphPad Software, La Jolla, CA, USA) and XLSTAT (Addinsoft, New York, NY, USA). Data is reported as the mean values with standard deviation and one way analysis of variance (ANOVA) with Fisher's least significant difference (LSD) multiple comparison test $(\mathrm{p}<0.05)$ to determine statistical significance. Principal component analysis (PCA) was conducted using The Unscrambler X v10.1 (CAMO Software, Oslo, Norway) and utilised standard scores derived from the volatile compound concentrations measured in each wine sample. 


\section{Results and Discussion}

\subsection{Dilution and addition of nutrients reduced alcoholic and malolactic fermentation duration}

Both alcoholic (AF) and malolactic fermentation (MLF) duration were shortened in diluted juices, as is expected where initial sugar concentrations were reduced (AF, Fig. 1 and 2; MF, data not shown). For instance, AF of juice diluted from 16 Bé to 12.5 Bé was reduced in duration with the use of Lalvin EC1118 ${ }^{\mathrm{TM}}$ by 126 hours, or 42\% (298 vs $172 \mathrm{~h}$ ). AF of undiluted juices by Lalvin $\mathrm{R} 2^{\mathrm{TM}}$ was slightly longer (in comparison to Lalvin $\mathrm{EC} 1118^{\mathrm{TM}}$ ), however, dilution resulted in a similar reduction of fermentation duration of 121 hours or 34\% (355 v 234 h). Dilution to 13.5 Bé or below also allowed the completion of MLF within 45 days in wines fermented by either yeast, whereas MLF of higher Baumé juices failed to complete in this time frame, leaving residual malic $\operatorname{acid}\left(>1.0 \mathrm{~g} \mathrm{~L}^{-1}\right)$ (Supp. Tab. 1). The very slow MLF in these conditions is thought to be particular to this juice, perhaps due to limitation of a micronutrient or presence of an inhibitor.

161 The effect on fermentation dynamics of diluted juices with nutrient addition was also evaluated, this 162 was in an effort to alleviate effects, if any, of micronutrient dilution. Additions were made at an 163 industry standard rate, as recommended by the manufacturer $\left(200 \mathrm{mg} \mathrm{L}^{-1}\right)$ and also at a higher rate 164 (400 $\left.\mathrm{m} \mathrm{L} \mathrm{L}^{-1}\right)$. The addition of nutrient had no significant impact on AF duration by Lalvin $165 \mathrm{EC}_{1118^{\mathrm{TM}}}$ in any juice (data not shown), however, fermentations by Lalvin R2 ${ }^{\mathrm{TM}}$, were up to 76 166 hours (26\%) shorter (Fig. 3). No difference in fermentation dynamics between juices supplemented 167 at either nutrient rate was observed, except in 13.5 Bé juice. Moreover, when either 200 or $400 \mathrm{mg}$ $168 \mathrm{~L}^{-1}$ of nutrient was added to 16 Bé juice, fermentation was reduced by 5 hours or 48 hours in 14.5 or 16912.5 Bé juices, respectively (data not shown). Whereas addition of $400 \mathrm{mg} \mathrm{L}^{-1}$ of nutrient added to 17013.5 Bé juices reduced fermentation by 76 hours in comparison to 52 hours when only $200 \mathrm{mg} \mathrm{L}^{-1}$ of 171 nutrient was added and malolactic acid bacteria (MLB) were present (Fig. 3). The presence of MLB 172 also had no effect on AF duration (Fig. 3). 
173 The addition of nutrient shortened MLF. Juice diluted to 13.5 Bé with 200 or $400 \mathrm{mg} \mathrm{L}^{-1}$ of nutrient 174 and with AF undertaken by Lalvin EC1118 ${ }^{\mathrm{TM}}$ completed MLF in 47 hours less (4.7\% reduction)

175 than when no nutrient was added (Supplementary Table 1).

\subsection{Dilution and nutrient addition changed the chemical composition of wines}

\section{The effect of juice dilution on volatile compounds and major yeast metabolites of the resulting} wines was examined. Similar to other studies (Schelezki et al., 2020; Schelezki, Suklje, et al., 2018), the dilution of juices modified the final concentrations of many compounds. Of the 38 volatile compounds analysed, 22 were significantly different to the control in at least three treatments (Table 1) with 19 influenced by dilution and 17 by nutrient addition. In almost all cases, dilution of juices resulted in a reduction in the concentration of volatiles, presumably by dilution of juice-derived precursors that arise from major metabolic pathways such as glycolysis. This is outcome is similar to that seen by Schelezki et al. (2020) where many compounds were reported to decrease upon addition of water to Shiraz juice prior to fermentation.

2-Phenylethanol, described as contributing aromas of rose, honey and spice, was detected in all fermentations above its aroma threshold, $14 \mathrm{mg} \mathrm{L}^{-1}$ (Ferreira, Lopez, \& Cacho, 2000), and with almost all dilutions was significantly reduced ( $70-49 \%$ or -1.44 to -2.02 Fold change (FC)). Its ester, 2-phenylethyl acetate was also reduced with dilution ( $62-19 \%$ or -1.62 to $-5.31 \mathrm{FC})$. In undiluted fermentations, isoamyl alcohol and, in fermentations conducted with Lalvin $\mathrm{R} 2^{\mathrm{TM}}$, its ester, isoamyl acetate were also detected above their aroma thresholds. Isoamyl acetate could be reduced to below its aroma threshold with any of the trialled dilutions (Fig. 4). Typically, isoamyl acetate was reduced to around $20 \%$ of the control $\left(6+/-3\right.$ to $13+/-9$ vs $56+/-3 \mu \mathrm{g} \mathrm{L}^{-1}$, Supp. Tab. 2). This ester can contribute an overpowering banana aroma, especially in white wines, and as such, a dilution strategy (where grapes have an elevated Bé) may represent an option for desirable flavour modification during winemaking. 
197 Acetic acid was also reduced in diluted fermentations conducted with Lalvin $\mathrm{R} 2^{\mathrm{TM}}$, for instance,

$198 \quad 3.57 \mathrm{mg} \mathrm{L}^{-1}$ was measured in wines using undiluted juice, whilst dilution to 13.5 Bé dramatically

199 reduced acetic acid concentrations to $0.8 \mathrm{mg} \mathrm{L}^{-1}$. Even though the aroma threshold of acetic acid is

$200200 \mathrm{mg} \mathrm{L}^{-1}$ (Ferreira et al., 2000), given that this compound is one of the most common faults in

201 wine, even at low concentrations this small difference could impact wine quality. The primary

202 alcohols 3 and 4-methyl-1-pentanol were significantly reduced in almost all diluted juices. For

203 instance, with the use of Lalvin $\mathrm{EC} 1118^{\mathrm{TM}}, 3$-methyl-1-pentanol was reduced to $31 \%$ (-3.23 FC) of

204 the control at the most extreme dilution (12.5 Bé). Aromatically, 3-methyl-1-pentanol is described

205 as contributing earthy and green notes, whereas for 4-methyl-1-pentanol its main descriptor is

206 'nutty', however their aroma detection thresholds are near 500 and $50,000 \mu \mathrm{g} \mathrm{L}^{-1}$, respectively

207 (Moreno, Zea, Moyano, \& Medina, 2005), many magnitudes above that detected here. If

208 considering these compounds individually we would expect the contribution here to wine aroma to

209 be minimal. It is however widely accepted that many subtle changes in volatile components could

210 result in detectable differences in overall wine aroma, and the individual effects of compounds on

211 the sensory attributes of wine can be complicated by many factors such as the interaction with other

212 wine compounds (Escudero, Campo, Fariña, Cacho, \& Ferreira, 2007). Ethyl acetate was also

213 commonly reduced in wines made from diluted juices with either yeast, whereas many more

214 compounds were detected as decreased in diluted juices fermented with Lalvin $\mathrm{R} 2^{\mathrm{TM}}$ i.e., butanoic

215 acid, ethyl butanoate, 2-methyl-4-vinylphenol, ethyl decanoate, isobutyl acetate, benzyl alcohol and

216 hexyl acetate. The single volatile that increased with dilution of juice in this analysis was methionol

217 (sweet potato aroma), but was only significant for the dilution to 14.5 Bé and with the use of Lalvin $218 \mathrm{R} 2^{\mathrm{TM}}$.

219 Some major yeast metabolites were also affected by juice dilution (Supp. Tab. 2 - 4). As expected 220 these decreased in concentration in proportion to juice dilution, for example ratios of malic and 221 succinic acid, glycerol and ethanol decreased (ranging from 0.92 to 0.67 , Supp. Tab. 4) to very similar ratios to that of juice dilution (14.5-12.5 Bé being 0.89-0.76; juice:water). This confirms 
the expectation that the major determinate of the final concentrations of these compounds is the initial concentration of sugars in juice. Only the concentration of acetaldehyde increased when juices were diluted to 13.5 or 14.5 Bé and fermented by Lalvin $\mathrm{R} 2^{\mathrm{TM}}$ (167 and 197\% respectively). Pyruvate decarboxylase forms acetaldehyde from pyruvate in the latter stages of glycolysis and then alcohol dehydrogenase reduces it to ethanol (Pronk, Yde Steenema, \& Van Dijken, 1996). This reaction importantly regenerates $\mathrm{NAD}^{+}$from $\mathrm{NADH}$. The accumulation of acetaldehyde is influenced by the expression and subsequent activity of alcohol dehydrogenases and particularly by the availability of its cofactor, NADH (Xu, Bao, et al., 2019). Transient accumulation of acetaldehyde has also been linked to decreased activity of NADP-dependent acetaldehyde dehydrogenase, which converts acetaldehyde to acetate (Remize, Andrieu, \& Dequin, 2000). This may also explain the reduction in acetic acid accumulation in the present study with fermentation by 234 Lalvin $\mathrm{R} 2^{\mathrm{TM}}$, especially as it is reduced beyond that expected from dilution alone (at 13.5 Bé reduced to $28 \%$ and 12.5 Bé to $22 \%(-3.54$ and $-4.45 \mathrm{FC})$ of undiluted juice fermentations, Table 1$)$.

236 Perhaps this indicates that the cumulative effect of juice dilution is a reduction of the activity of 237 alcohol dehydrogenase and/or acetaldehyde dehydrogenase, through modification of the $\mathrm{NAD}^{+} / \mathrm{H}$ or $238 \mathrm{NADP} / \mathrm{H}$ pools. Dilution of juices is expected to change the external osmolarity that yeast 239 experience at the beginning of fermentation, and it is well documented that many metabolic 240 processes are affected (Varela \& Mager, 1996). These minor adjustments of redox cofactors may 241 reflect how the cell achieves balance under these different initial osmotic conditions and results in 242 changes to compound concentrations, such as acetaldehyde and acetic acid reported here.

243 Interestingly, glycerol, the main compound involved in balancing redox factors in response to 244 osmotic stress, is relatively unaffected, only reducing in proportion to juice dilution (Supp. Tab. 4).

245 We were also particularly interested to see if nutrient addition could recover volatile concentrations 246 to those similar to undiluted juices, supposedly by re-supplying diluted precursors. Of the volatile 247 compounds that were significantly different with addition of nutrient, the vast majority were increased (44 from 56 data points, Table 1), however these rarely recovered the concentration found 
in undiluted juices. In some conditions, ethyl lactate could be recovered (Supp. Fig 1). Compounds

250 found to increase with the addition of nutrient in more than one condition included 3 and 4-methyl251 1-pentanol (up to 129\%), butanoic acid (up to 166\%), ethyl butanoate (up to $120 \%$ ), hexanoic acid 252 (up to 141\%) and octanoic acid (up to 346\%), ethyl lactate (up to 131\%) and isobutyric acid (up to 168\%; Table 1). Interestingly the occurrence of fatty acids, hexanoic and octanoic acid was unaffected by juice dilution, but consistently increased with nutrient addition (octanoic: 215-346\%, 255 hexanoic: 125-141\%). This is akin to that seen by other studies (Torrea, Varela, Ugliano, Ancin256 Azpilicueta, Leigh Francis, \& Henschke, 2011). Similarly, the fatty acid, butanoic acid, also 257 increased with addition of nutrients, however in contrast to hexanoic and octanoic acids, in wines 258 fermented by Lalvin $\mathrm{R} 2^{\mathrm{TM}}$, dilution did result in reduced butanoic acid. Torrea and colleagues 259 (2003) suggest an increase in medium chain fatty acids could simply be due to a relative increase in 260 fatty acid synthesis due to nitrogen supplementation. Fatty acids are produced during fermentation by the fatty acid synthase (FAS) complex from acetyl-CoA and malonyl-CoA during lipid synthesis (Taylor \& Kirsop, 1977) with the main source of acetyl CoA during anaerobiosis being acetic acid (Chen, Siewers, \& Nielsen, 2012). A number of factors could influence the activity of the enzymes involved and availability of acetyl-CoA in the cytosol such as the supply of cofactors like NADPH (Bloem, Sanchez, Dequin, \& Camarasa, 2016) and availability of nutrients (Chen et al., 2012). The mechanism leading to accumulation of medium chain fatty acids under these conditions is still debated but likely involves premature release from the FAS complex due to feedback inhibition by saturated fatty acids and/or an increase in the fatty acid synthetic pathway (Duffour, Malcorps, \& Silcock, 2003; Saerens, Delvaux, Verstrepen, Van Dijck, Thevelein, \& Delvaux, 2008). Perhaps saturated fatty acids from the complex nutrient contributed to this release of medium chain fatty 271 acids. These commercial preparations commonly contain inactivated yeast and as such have a component of fatty acids along with amino acids, peptides, proteins, polysaccharides, nucleotides,

273 vitamins (thiamine, biotin, pantothenic acid) and minerals (magnesium and zinc) (Lallemand, 2019; 274 Pozo-Bayón, Andújar-Ortiz, \& Moreno-Arribas, 2009). However, yeasts for this purpose are grown 
with plentiful oxygen, and thus saturated fatty acids should be far exceed the concentration of nonsaturated fatty acids thus reducing the possibility of feedback inhibition of the FAS complex. Changes to the redox status of yeast have also been shown to affect volatiles produced by yeast (Bloem et al., 2016). Of particular relevance to this study, Bloem and colleagues (2016) report decreased accumulation of medium chain fatty acids (hexanoic and octanoic) during increased demand for NADPH or NADH. As hexanoic, octanoic and butanoic acids were detected many magnitudes above their aroma threshold (hexanoic: $420 \mu \mathrm{g} \mathrm{L}{ }^{-1}$ (Guth, 1997), octanoic: $500 \mu \mathrm{g} \mathrm{L}^{-1}$ and butanoic: $173 \mu \mathrm{g} \mathrm{L}^{-1}$ (Ferreira et al., 2000)), we expect these difference would translate to a sensorial difference. This group of compounds is commonly described as sweaty and cheesy. The presence of fatty acids have also been shown to translate to increases in their fatty acid ethyl ester, for instance ethyl hexanoate and ethyl butanoate (Saerens et al., 2008; Saerens et al., 2006). In this study, the sensorially desirable esters, ethyl lactate and ethyl butanoate, increased with the addition of nutrient (up to 131 and $120 \%$, respectively in wines fermented by Lalvin R2 ${ }^{\mathrm{TM}}$ ). Ethyl lactate is described as fruity and ethyl butanoate as floral, fruity, and strawberry like, but in this study they occurred below their aroma thresholds. Exogenously added amino acids have been suggested to be direct precursors of esters, however studies report variable effects of changes in nutrition upon the ester composition of wine, which may be a reflection of changes in juice composition, yeast strain and amount and timing of additions (Hernández-Orte, Ibarz, Cacho, \& Ferreira, 2005; Torrea et al., 2011).

Both 3 and 4-methyl-1-pentanol increase with the addition of nutrient in the order of $9-29 \%$, in comparison to wine made from the juice of the same Bé. The most consistent increases of these compounds occurred with addition of $400 \mathrm{mg} \mathrm{L}^{-1}$ nutrient, however the magnitude of increases was always well below that of the effect of the initial dilution, thus not resulting in full recovery of reduced volatiles caused by dilution. An increase in these compounds may simply reflect an 
increase in flux through glycolysis and/or fatty acid synthesis as the 2-keto acid precursors for their

301 formation might be originally derived from pyruvate, as has been shown possible with synthetic pathways built from a combination of yeast and bacterial genes with the goal of efficient production of these compounds for biofuel (Zhang, Sawaya, Eisenberg, \& Liao, 2008). This is supported since the Saccharomyces cerevisiae enzyme Adh6p, an alcohol dehydrogenase with a strict specificity for $\mathrm{NADPH}$, is capable of completing the final step in formation of methyl pentanols (Zhang et al., 307 limited to 5-carbon chains as determined by amino acid precursors (Hazelwood, Daran, van Maris, 308 Pronk, \& Dickinson, 2008). 2-Methyl-4-vinylphenol, methyl octanoate, methyl decanoate, acetic 309 acid and ethyl acetate and methionol were found to decrease with the addition of nutrient in selected 310 conditions (Table 1), with methionol being previously reported to decrease with exogenous 311 additions of nitrogen (ca. 70\%; Hernández-Orte et al., 2005).

312 Few differences in major metabolites were detected with added nutrient (Supp. Tab. 4). The most 313 prominent, as with dilution, was an increase of acetaldehyde. Whether this is simply a reflection of 314 increased flux through the glycolytic pathway or accumulation due to reduced availability of 315 cofactors to drive the activity of alcohol dehydrogenases remains to be proven. Acetaldehyde is 316 generally regarded as undesirable when occurring above $100-125 \mathrm{mg} \mathrm{L}^{-1}$, as occurred in this study $317 \quad\left(120-330 \mathrm{mg} \mathrm{L}^{-1}\right)$.

318 Principal Component Analysis of measured volatiles highlighted the interaction between dilution 319 and yeast strain, with the effect of both of these variables on wine volatile compound composition 320 being explained by both of the first 2 principal components (Fig. 5). Wines made with either yeast 321 and from diluted juices were clearly separated, with wines made with Lalvin EC1118 ${ }^{\mathrm{TM}}$ located 322 more towards the right and the top of the score plot (i.e. they had more positive PC1 and PC2 323 values) compared to the comparable juices fermented with Lalvin $\mathrm{R} 2^{\mathrm{TM}}$. The clear separation of 324 these yeasts supports what is widely known in the winemaking industry as Lalvin $\mathrm{R} 2^{\mathrm{TM}}$ can make a 
significant contribution to wine aroma, thereby it is marketed as "aromatic", whereas Lalvin $\mathrm{EC} 1118^{\mathrm{TM}}$ is considered "neutral". Wines also grouped according to their juice dilution with higher Bé cultures being located toward the left and top of the plot compared to those with lower Bé (Fig. 5). No clear trend appears to be associated with nutrient additions, reflecting the differential effects depending upon the compound.

\section{Conclusions}

In this study juice dilution does not impede microbial fermentation, but instead results in reduction of both alcoholic and malolactic fermentation duration and changes to the chemical composition of wines. Nutrient addition was also effective in shortening fermentation duration by Lalvin $\mathrm{R} 2^{\mathrm{TM}}$ by up to $26 \%$. Compounds that were significantly affected in more than 3 treatments by either dilution or nutrient addition and detected above their aroma thresholds were isoamyl acetate, isoamyl alcohol, 2-phenylethanol, methionol and hexanoic, butanoic and octanoic acids. Isoamyl acetate and isoamyl alcohol (banana aroma) and 2-phenylethanol (rose) were reduced by dilution, but the effect upon methionol (sweet potato aroma) varied depending on the treatment. Also the addition of complex organic nutrient, irrespective of dilution rate resulted in increased medium chain fatty acids (hexanoic, butanoic and octanoic characterised by sweaty, cheesy and rancid aromas). The concentrations of 22 volatile compounds were significantly different in three or more treatments. In

342 fact a single treatment resulted in modifications to as many as 15 different volatile compounds and 343 even if these are not above their aroma threshold values, they may act in concert to result in global 344 changes to wine aroma (Escudero et al., 2007). Sensory studies would be of great benefit to 345 determine which of these impacts result in wines that are detectably different to consumers. 346 Depending on the target wine style, these changes may be regarded as a desirable outcome.

347 Winemakers should take into consideration the potential impacts of juice dilution, as well as yeast 348 choice on both processing efficiencies as well as effect on the aroma and flavour of wine. 


\section{Acknowledgements}

351 This work was supported by Wine Australia, Adelaide, South Australia (grant number, UA 1803352 2.1). VJ is supported by The Australian Research Council Training Centre for Innovative Wine 353 Production (www.ARCwinecentre.org.au; project number IC170100008), which is funded by the 354 Australian Government with additional support from Wine Australia and industry partners. The 355 University of Adelaide is a member of the Wine Innovation Cluster in Adelaide 356 (http://www.thewaite.org/waite-partners/wine-innovation-cluster/). We also thank Mr Nick van 357 Holst Pellekaan and Dr Jin Zhang for technical assistance during setting up of the fermentations and HPLC analysis and Sue Maffei and Emily Nicholson for assistance with the wine volatile compound analysis. Finally we also thank Lallemand for supply of microbes and complex organic nutrient.

\section{Conflicts of Interest}

We wish to confirm that there are no known conflicts of interest associated with this publication and there has been no significant financial support for this work that could have influenced its outcome.

\section{References}

Bell, S. J., \& Henschke, P. A. (2005). Implications of nitrogen nutrition for grapes, fermentation and wine. Australian Journal of Grape and Wine Research, 11(3), 242-295.

Bloem, A., Sanchez, I., Dequin, S., \& Camarasa, C. (2016). Metabolic impact of redox cofactor perturbations on the formation of aroma compounds in Saccharomyces cerevisiae. Appl Environ Microbiol, 82(1), 174-183. https://doi.org/10.1128/AEM.02429-15.

Boss, P. K., Pearce, A. D., Zhao, Y. J., Nicholson, E. L., Dennis, E. G., \& Jeffery, D. W. (2015). Potential grape-derived contributions to volatile ester concentrations in wine. Molecules, 20(5), 7845-7873. https://doi.org/10.3390/molecules20057845. 
Chen, Y., Siewers, V., \& Nielsen, J. (2012). Profiling of cytosolic and peroxisomal Acetyl-CoA metabolism in Saccharomyces cerevisiae. PLoS One, 7(8), e42475. https://doi.org/10.1371/journal.pone.0042475.

Cowey, G. (2017). Making water additions to high sugar must. AWRI Technical Review, 227, 9-12.

Duffour, J., Malcorps, P., \& Silcock, P. (2003). Control of Ester Synthesis During Brewery Fermentation. In Brewing Yeast Fermentation Performance (pp. 213-233).

Escudero, A., Campo, E., Fariña, L., Cacho, J., \& Ferreira, V. (2007). Analytical characterization of the aroma of five premium red wines. insights into the role of odor families and the concept of fruitiness of wines. Journal of Agricultural and Food Chemistry, 55(11), 4501-4510. https://doi.org/10.1021/jf0636418.

Etievant, P. X. (1991). Volatile compounds in foods and beverages. In H. Maarse (Ed.), Food science and technology ; 44 (pp. 483-546). New York, N.Y: Marcel Dekker.

Ferreira, V., Lopez, R., \& Cacho, J. F. (2000). Quantitative determination of the odorants of young red wines from different grape varieties. Journal of the Science of Food and Agriculture, 80(11), 1659-1667. https://doi.org/Doi 10.1002/1097-0010(20000901)80:11<1659::AidJsfa693>3.0.Co;2-6.

Gomez-Miguez, M. J., Cacho, J. F., Ferreira, V., Vicario, I. M., \& Heredia, F. J. (2007). Volatile components of Zalema white wines. Food Chemistry, 100(4), 1464-1473. https://doi.org/10.1016/j.foodchem.2005.11.045.

Guth, H. (1997). Quantitation and sensory studies of character impact odorants of different white wine varieties. Journal of Agricultural and Food Chemistry, 45(8), 3027-3032. https://doi.org/DOI 10.1021/jf970280a.

Harbertson, J. F., Mireles, M. S., Harwood, E. D., Weller, K. M., \& Ross, C. F. (2009). Chemical and sensory effects of saignée, water addition, and extended maceration on high brix must. American Journal of Enology and Viticulture, 60(4), 450-460. https://www.ajevonline.org/content/ajev/60/4/450.full.pdf. 
Hazelwood, L. A., Daran, J. M., van Maris, A. J., Pronk, J. T., \& Dickinson, J. R. (2008). The Ehrlich pathway for fusel alcohol production: a century of research on Saccharomyces cerevisiae metabolism. Appl Environ Microbiol, 74(8), 2259-2266. http://www.ncbi.nlm.nih.gov/entrez/query.fcgi? $\mathrm{cmd}=$ Retrieve $\& \mathrm{db}=\mathrm{PubMed} \& \mathrm{dopt}=\mathrm{Citation}$ \&list_uids=18281432.

Hernández-Orte, P., Ibarz, M. J., Cacho, J., \& Ferreira, V. (2005). Effect of the addition of ammonium and amino acids to musts of Airen variety on aromatic composition and sensory properties of the obtained wine. Food Chemistry, 89(2), 163-174. https://doi.org/https://doi.org/10.1016/j.foodchem.2004.02.021.

Hranilovic, A., Li, S., Boss, P. K., Bindon, K., Ristic, R., Grbin, P. R., Van der Westhuizen T., \& Jiranek, V. (2018). Chemical and sensory profiling of Shiraz wines co-fermented with commercial non-Saccharomyces inocula. Australian Journal of Grape and Wine Research,

Jiang, J., Sumby, K. M., Sundstrom, J. F., Grbin, P. R., \& Jiranek, V. (2018). Directed evolution of Oenococcus oeni strains for more efficient malolactic fermentation in a multi-stressor wine environment. Food Microbiol, 73, 150-159. https://doi.org/10.1016/j.fm.2018.01.005.

Lallemand. (2019). Fermaid O Natural Yeast Derived Nutrient. Retrieved from: https://catalogapp.lallemandwine.com/uploads/nutrient/docs/f4a473f989e161ecc34cae1cedd 6058cefb223b2.pdf. Accessed 1.7.20.

Lin, M. M.-H., Boss, P. K., Walker, M. E., Sumby, K. M., Grbin, P. R., \& Jiranek, V. (2020). Evaluation of indigenous non-Saccharomyces yeasts isolated from a South Australian vineyard for their potential as wine starter cultures. International Journal of Food Microbiology, 312, 108373. https://doi.org/https://doi.org/10.1016/j.ijfoodmicro.2019.108373. 
Moreno, J. A., Zea, L., Moyano, L., \& Medina, M. (2005). Aroma compounds as markers of the changes in sherry wines subjected to biological ageing. Food Control, 16(4), 333-338. https://doi.org/10.1016/j.foodcont.2004.03.013.

Peinado, R. A., Moreno, J., Bueno, J. E., Moreno, J. A., \& Mauricio, J. C. (2004). Comparative study of aromatic compounds in two young white wines subjected to pre-fermentative cryomaceration. Food Chemistry, 84(4), 585-590. https://doi.org/10.1016/S03088146(03)00282-6.

Petrie, P. R., Teng, B., Smith, P. A., \& Bindon, K. (2019). Managing high Baume juice using dilution. Wine and Viticulture Journal, Summer, 36-37.

Pozo-Bayón, M. Á., Andújar-Ortiz, I., \& Moreno-Arribas, M. V. (2009). Volatile profile and potential of inactive dry yeast-based winemaking additives to modify the volatile composition of wines. Journal of the Science of Food and Agriculture, 89(10), 1665-1673. https://doi.org/10.1002/jsfa.3638.

Pronk, J. T., Yde Steenema, H., \& Van Dijken, J. P. (1996). Pyruvate Metabolism in Saccharomyces cerevisiae. Yeast, 12(16), 1607-1633. https://doi.org/10.1002/(sici)10970061(199612)12:16<1607::Aid-yea70>3.0.Co;2-4.

Remize, F., Andrieu, E., \& Dequin, S. (2000). Engineering of the pyruvate dehydrogenase bypass in Saccharomyces cerevisiae: role of the cytosolic $\mathrm{Mg}\left({ }^{2+}\right)$ and mitochondrial $\mathrm{K}\left({ }^{+}\right)$acetaldehyde dehydrogenases Ald6p and Ald4p in acetate formation during alcoholic fermentation. Applied and Environmental Microbiology, 66(8), 3151-3159. https://doi.org/10.1128/aem.66.8.3151-3159.2000.

Saerens, S. M. G., Delvaux, F., Verstrepen, K. J., Van Dijck, P., Thevelein, J. M., \& Delvaux, F. R. (2008). Parameters affecting ethyl ester production by Saccharomyces cerevisiae during fermentation. Applied and Environmental Microbiology, 74(2), 454-461. https://doi.org/10.1128/aem.01616-07. 
Saerens, S. M. G., Verstrepen, K. J., Van Laere, S. D. M., Voet, A. R. D., Van Dijck, P., Delvaux, F. R., \& Thevelein, J. M. (2006). The Saccharomyces cerevisiae EHT1 and EEB1 genes encode novel enzymes with medium-chain fatty acid ethyl ester synthesis and hydrolysis capacity. Journal of Biological Chemistry, 281(7), 4446-4456. https://doi.org/10.1074/jbc.M512028200.

Salo, P. (1970). Determining the odor thresholds for some compounds in alcoholic beverages. Journal of Food Science, 35(1), 95-99. https://doi.org/10.1111/j.1365-2621.1970.tb12378.x.

Schelezki, O. J., Antalick, G., Šuklje, K., \& Jeffery, D. W. (2020). Pre-fermentation approaches to producing lower alcohol wines from Cabernet Sauvignon and Shiraz: Implications for wine quality based on chemical and sensory analysis. Food Chemistry, 309, 125698. https://doi.org/https://doi.org/10.1016/j.foodchem.2019.125698.

Schelezki, O. J., Smith, P. A., Hranilovic, A., Bindon, K. A., \& Jeffery, D. W. (2018). Comparison of consecutive harvests versus blending treatments to produce lower alcohol wines from Cabernet Sauvignon grapes: Impact on polysaccharide and tannin content and composition. Food Chemistry, 244, 50-59. https://doi.org/10.1016/j.foodchem.2017.10.024.

Schelezki, O. J., Suklje, K., Boss, P. K., \& Jeffery, D. W. (2018). Comparison of consecutive harvests versus blending treatments to produce lower alcohol wines from Cabernet

Schultz, H. R. (2016). Global climate change, sustainability, and some challenges for grape and wine production. Journal of Wine Economics, 11(1), 181-200. https://doi.org/10.1017/jwe.2015.31. Flavor Chemistry (pp. 223-237): American Chemical Society. 
Taylor, G. T., \& Kirsop, B. H. (1977). The origin of the medium chain length fatty acids in beer. Journal of the Institute of Brewing, 83(4), 241-243. https://doi.org/10.1002/j.20500416.1977.tb03802.x.

Teng, B., Petrie, P. R., Smith, P. A., \& Bindon, K. A. (2020). Comparison of water addition and early-harvest strategies to decrease alcohol concentration in Vitis vinifera cv. Shiraz wine: impact on wine phenolics, tannin composition and colour properties. Australian Journal of Grape and Wine Research, 26(2), 158-171. https://doi.org/10.1111/ajgw.12430.

Torrea, D., Fraile, P., Garde, T., \& Ancin, C. (2003). Production of volatile compounds in the fermentation of chardonnay musts inoculated with two strains of Saccharomyces cerevisiae with different nitrogen demands. Food Control, 14(8), 565-571. http://www.sciencedirect.com/science/article/B6T6S-482G9D2D/2/d6c8022a366b98e79e0e669480a62401.

Torrea, D., Varela, C., Ugliano, M., Ancin-Azpilicueta, C., Leigh Francis, I., \& Henschke, P. A. (2011). Comparison of inorganic and organic nitrogen supplementation of grape juice Effect on volatile composition and aroma profile of a Chardonnay wine fermented with Saccharomyces cerevisiae yeast. Food Chemistry, 127(3), 1072-1083. https://doi.org/https://doi.org/10.1016/j.foodchem.2011.01.092.

Varela, J. C. S., \& Mager, W. H. (1996). Response of Saccharomyces cerevisiae to changes in external osmolarity. Microbiology, 142(4), 721-731. https://doi.org/https://doi.org/10.1099/00221287-142-4-721.

Walker, M. E., Nguyen, T. D., Liccioli, T., Schmid, F., Kalatzis, N., Sundstrom, J. F., Gardner J. M., \& Jiranek, V. (2014). Genome-wide identification of the Fermentome; genes required for successful and timely completion of wine-like fermentation by Saccharomyces cerevisiae. BMC Genomics, 15, 17. https://doi.org/10.1186/1471-2164-15-552. 
Xu, X., Bao, M., Niu, C., Wang, J., Liu, C., Zheng, F., Yongxian, L., \& Li, Q. (2019). Engineering the cytosolic NADH availability in lager yeast to improve the aroma profile of beer. Biotechnology Letters, 41(3), 363-369. https://doi.org/10.1007/s10529-019-02653-x.

Zhang, K., Sawaya, M. R., Eisenberg, D. S., \& Liao, J. C. (2008). Expanding metabolism for biosynthesis of nonnatural alcohols. Proceedings of the National Academy of Sciences, 105(52), 20653-20658. https://doi.org/10.1073/pnas.0807157106.

\section{Figure Legends}

Figure 1. Sugar catabolism by Lalvin $\mathrm{EC} 1118^{\mathrm{TM}}(\mathrm{A})$ or Lalvin $\mathrm{R} 2^{\mathrm{TM}}(\mathrm{B})$ of 16 Bé juice $(\bullet)$ and juices diluted with water to $14.5(\square), 13.5(\triangle)$ and $12.5(\diamond)$ Bé without the addition of malolactic bacteria or complex organic nutrient. Data presented are the average of triplicate fermentations, with the error bars representing the standard deviation.

Figure 2. Alcoholic fermentation duration of Lalvin $\mathrm{EC} 1118^{\mathrm{TM}}(\mathrm{EC})$ and Lalvin $\mathrm{R} 2^{\mathrm{TM}}(\mathrm{R} 2)$, with $(\mathrm{MLB}+)$ and without (MLB-) malolactic bacteria. 16 Bé juice was either fermented neat ( $\mathbf{})$, or diluted with water to $14.5(\square), 13.5(\square)$ or $12.5(\square)$ Bé. Data presented is the average of triplicate fermentations and includes standard deviations. *Significantly different to fermentation duration of 16 Bé juice within the set (same yeast and MLB treatment), one way ANOVA, $\mathrm{p}<0.05$.

Figure 3. Alcoholic fermentation duration of Lalvin $\mathrm{R} 2^{\mathrm{TM}}$, in juice diluted to 13.5 Bé with (MLB+) and without (MLB-) malolactic bacteria and with the addition of complex organic nutrient at 0 ( ), $200(\square)$ or $400(\square) \mathrm{mg} \mathrm{L}^{-1}$. Data presented is the average of triplicate fermentations and includes standard deviations. Values with different letters are significantly different, one way ANOVA, $\mathrm{p}<$ 0.05 .

Figure 4. Isoamyl acetate measured in wines (GC-MS) fermented by Lalvin EC1118 ${ }^{\mathrm{TM}}$ or Lalvin R2 ${ }^{\mathrm{TM}}$ with no malolactic bacteria added. Wines were made from juice with initial Bé of 16 or 
diluted with water to $14.5,13.5$ or 12.5 . Nutrient was also added to juices; $0($ ), $200(\square)$ or 400

523

(ש) $\mathrm{mg} \mathrm{L}^{-1}$. Dashed line represents aroma threshold of isoamyl acetate $\left(30 \mu \mathrm{g} \mathrm{L}{ }^{-1}\right.$ (Guth, 1997)). *significantly different to 16.0 Bé with no nutrient added (for the same yeast), one way ANOVA, p $<0.05)$.

Figure 5. Principal Component Analysis scores plot of volatiles (based on 39 compounds measured by GC-MS) in wines fermented by Lalvin EC1118 ${ }^{\mathrm{TM}}$ (EC) or Lalvin R2 ${ }^{\mathrm{TM}}$ (R2). Wines made from juice with initial Bé of 16, 14.5 (14), 13.5 (13) and 12.5 (12) with the addition of 0,200 (20) or 400 (40) $\mathrm{mg} \mathrm{L}^{-1}$ nutrient. The first two axes are shown (PC-1 and PC-2).

Table 1. Volatiles detected in final wines that were significantly different (one way ANOVA, $\mathrm{p}<$ 0.05 ) to the matched control (no nutrient added 16 Bé juice fermented by either Lalvin EC1118 ${ }^{\mathrm{TM}}$ or Lalvin $\mathrm{R} 2{ }^{\mathrm{TM}}$ with no exogenous nutrient added, or where nutrients were added comparison was to the same Be juice with no nutrients added). Where a significant difference was detected, the fold change difference of treatment to control is shown. Volatiles that increased upon dilution are shaded in green and decreased in red. - no significant difference. Actual values $\left(\mu \mathrm{g} \mathrm{L}^{-1}\right)$ are shown for undiluted juices. Aroma threshold as reported in ${ }^{\mathrm{a}}$ Moreno et al. (2005), ${ }^{\mathrm{b}} \mathrm{Guth}$ (1997), ${ }^{\mathrm{c}}$ Ferreira et al. (2000), ${ }^{\mathrm{d}}$ Peinado, Moreno, Bueno, Moreno, \& Mauricio (2004); Salo (1970), ${ }^{\mathrm{e}}$ Etievant (1991), ${ }^{\mathrm{f}}$ Takeoka et al. (1989), ${ }^{\mathrm{g}}$ Gomez-Miguez, Cacho, Ferreira, Vicario, \& Heredia (2007). *Volatiles detected above the aroma threshold in at least one treatment.

\section{Supplementary legends}

Supplementary Table 1. Residual malic acid after 1122 hours or hours taken to metabolise all malic acid $\left(<0.2 \mathrm{~g} \mathrm{~L}^{-1}\right)$ by VP 41 when co-inoculated with either $\mathrm{EC} 1118^{\mathrm{TM}}$ or Lalvin $\mathrm{R} 2^{\mathrm{TM}}$ in juice at 16 Bé or a range of dilutions with either 0,200 or $400 \mathrm{mg} \mathrm{L}^{-1}$ of complex organic nutrient. Values are the average of triplicates $+/-$ Standard deviations. *Significantly different to no nutrient added (same Bé), Student's t-test. 
546 Supplementary Table 2. Volatile and major yeast metabolic compounds $\left(\mu \mathrm{g}^{-1}+/\right.$ - standard 547 deviations) detected in final wines for all treatments except for those inoculated with lactic acid 548 bacteria for malolactic fermentation. No yeast controls were also analysed, in most cases volatiles 549 were below detection limits, where they were measured they were many magnitudes lower than 550 fermented treatments and thus the data is not shown.

551 Supplementary Table 3. Volatile and major yeast metabolic compounds (volatiles: $\mu \mathrm{g} \mathrm{L}^{-1}$ and 552 major metabolites $\mathrm{g} \mathrm{L}^{-1}$ ) detected in final wines for all treatments except for those inoculated with 553 lactic acid bacteria for malolactic fermentation. No yeast controls were also analysed, in most cases 554 volatiles were below detection limits, where they were measured they were many magnitudes lower 555 than fermented treatments and thus the data is not shown. Blue highlighted cells indicate those 556 measurements significantly different due to juice dilution (compared to the same yeast at 16 Bé) 557 and orange highlighted cells indicate those significantly different due to nutrient addition (compared 558 to the same yeast and same initial Bé juice). Significant differences were determined by ANOVA 559 and significantly different data are indicated by different letters.

560 Supplementary Table 4. Ratios of significantly different compounds measured by HPLC. Ratios 561 of compounds detected in wines made from diluted juices are in comparison to 16 Bé juices 562 fermented by the same yeast, or in the case of where nutrient is added, to wines made from juices of 563 the same Bé. Increased ratios are highlighted in green and decreased in red. Results for wines made 564 from 16 Bé juices with no nutrient addition are displayed as actual values $\left(\mathrm{g} \mathrm{L}^{-1}\right)+/-\mathrm{SD}$. Significant differences were determined by ANOVA.

566 Supplementary Figure 1. Ethyl lactate measured in wines (GC-MS) fermented by Lalvin R2 ${ }^{\mathrm{TM}}$ 567 with no malolactic bacteria added. Wines were made from juice with initial Bé of 16 or diluted with 568 water to $14.5,13.5$ or 12.5 . Nutrient was also added to juices; $0(\quad), 200(\square)$ or $400(\square) \mathrm{mg} \mathrm{L}^{-1}$. 569 Dashed line represents aroma threshold of isoamyl acetate (30 $\mu \mathrm{g} \mathrm{L}^{-1}$ (Guth, 1997)). Significantly 
bioRxiv preprint doi: https://doi.org/10.1101/2020.07.29.226142; this version posted July 30, 2020. The copyright holder for this preprint (which was not certified by peer review) is the author/funder. All rights reserved. No reuse allowed without permission.

570 different values are labelled with different letters or letter groups (a-d), one way ANOVA, $\mathrm{p}<$ $571 \quad 0.05)$

572

573

574 
Table 1. Gardner et al.

\begin{tabular}{|c|c|c|c|c|c|c|c|c|c|c|c|c|c|c|c|c|c|c|c|c|c|c|c|c|}
\hline & & 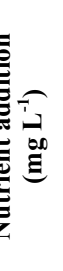 & 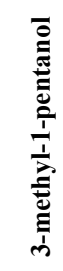 & 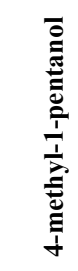 & 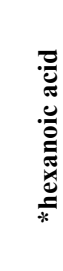 & 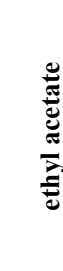 & 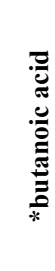 & 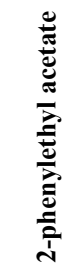 & 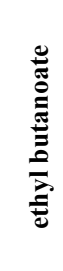 & 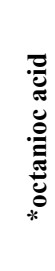 & 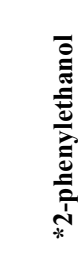 & 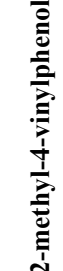 & 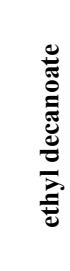 & 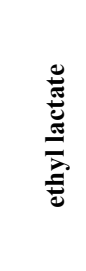 & 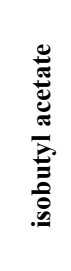 & 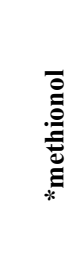 & 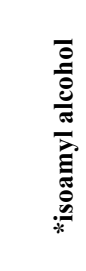 & 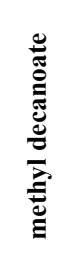 & 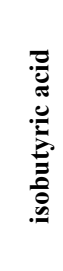 & 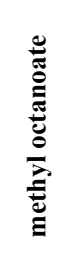 & 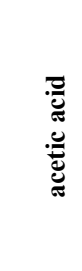 & $\begin{array}{l}\bar{\Xi} \\
\frac{\bar{e}}{\sigma} \\
\bar{\delta} \\
\bar{\Xi}\end{array}$ & 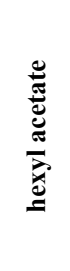 & 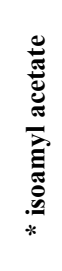 \\
\hline & $\begin{array}{l}m \\
\left(\mu \mathrm{g} \mathrm{L}^{-1}\right)\end{array}$ & & $500^{\mathrm{a}}$ & $50000^{\mathrm{a}}$ & $3000^{b}$ & $7500^{\mathrm{b}}$ & $173^{c}$ & $250^{b}$ & $20^{\mathrm{b}}$ & $500^{\circ}$ & $14000^{\circ}$ & N/A & $200^{\circ}$ & $14000^{d}$ & $1600^{\circ}$ & $1000^{\circ}$ & $30000^{b}$ & $\mathrm{~N} / \mathrm{A}$ & $2300^{\circ}$ & $200^{f}$ & $2 \times 10^{5 b}$ & $2 \times 10^{58}$ & $670^{\circ}$ & $30^{\mathrm{b}}$ \\
\hline & 16 Bé & 0 & $\begin{array}{c}217 \\
+/ . \\
16\end{array}$ & $\begin{array}{l}650 \\
+/- \\
21\end{array}$ & $\begin{array}{c}6,107 \\
+/ \\
384\end{array}$ & $\begin{array}{c}1,769 \\
+/ . \\
228\end{array}$ & $\begin{array}{l}895 \\
+- \\
149\end{array}$ & $\begin{array}{l}4.8 \\
+1 / \\
1.6\end{array}$ & $\begin{array}{l}6.9 \\
+/ . \\
0.8\end{array}$ & $\begin{array}{c}222 \\
+/- \\
49\end{array}$ & $\begin{array}{c}171614 \\
+\gamma \\
17567\end{array}$ & $\begin{array}{c}2544 \\
+/ . \\
787\end{array}$ & $\begin{array}{l}20 \\
+/ . \\
3\end{array}$ & $\begin{array}{l}3.91 \\
++- \\
0.24\end{array}$ & $\begin{array}{l}0.35 \\
+\neq \\
0.1\end{array}$ & $\begin{array}{c}1297 \\
+1- \\
43\end{array}$ & $\begin{array}{c}145139 \\
+/ \\
13654\end{array}$ & $\begin{array}{l}0.65 \\
++- \\
0.46\end{array}$ & $\begin{array}{c}601 \\
+- \\
90\end{array}$ & $\begin{array}{l}5.9 \\
+\neq \\
3.54\end{array}$ & $\begin{array}{l}260 \\
+/ . \\
178\end{array}$ & $\begin{array}{c}37 \\
+/ 2 \\
5\end{array}$ & $\begin{array}{l}0.34 \\
+1- \\
0.07\end{array}$ & $\begin{array}{c}20 \\
+/- \\
8\end{array}$ \\
\hline & & 200 & 1.09 & 1.11 & 1.39 & - & - & - & - & - & - & - & - & - & - & - & - & - & - & - & - & - & - & - \\
\hline & & 400 & 1.24 & 1.22 & 1.37 & 1.16 & - & - & - & 3.13 & - & -1.66 & 1.84 & - & 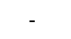 & 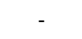 & 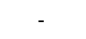 & 2.88 & 1.68 & & - & - & - & - \\
\hline & 14.5 Bé & 0 & -1.79 & -1.45 & & & - & -1.62 & & & -1.44 & & & & 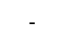 & & & & - & & - & - & - & \\
\hline$\Xi$ & & 200 & & - & 1.26 & - & - & - & - & - & - & - & - & - & - & - & - & - & - & - & - & - & - & - \\
\hline ర్త్ర & & 400 & - & 1.11 & - & - & - & - & - & 2.30 & - & - & - & - & & - & - & - & & - & & & & - \\
\hline & 13.5 Bé & 0 & -2.42 & -1.79 & - & -1.28 & - & -2.16 & - & - & -1.72 & 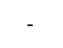 & 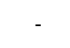 & - & - & - & -1.23 & - & - & & - & 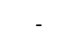 & - & \\
\hline & & 200 & - & - & - & - & & - & - & - & & - & - & - & & - & - & - & & - & & & & - \\
\hline & & 400 & & - & 1.36 & - & 1.66 & - & - & & - & -1.61 & - & & - & - & - & & 1.54 & & - & - & - & - \\
\hline & 12.5 Bé & 0 & -3.23 & -2.19 & & -1.47 & - & -2.86 & & & -2.02 & & & -1.25 & - & -1.79 & -1.29 & & - & & - & - & - & \\
\hline & & 200 & & - & 1.41 & & - & - & & & 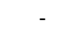 & & & & - & & & & - & -5.01 & - & - & - & \\
\hline & & 400 & & - & 1.37 & - & - & - & - & 2.15 & - & - & - & - & - & - & - & & - & & - & - & - & - \\
\hline & 16 Bé & 0 & $\begin{array}{l}282 \\
++-\end{array}$ & $\begin{array}{l}1647 \\
+-1\end{array}$ & $\begin{array}{l}5974 \\
+-\end{array}$ & $\begin{array}{l}1942 \\
+-1\end{array}$ & $\begin{array}{r}1019 \\
+/\end{array}$ & $\begin{array}{l}7.9 \\
+ \\
+-.9\end{array}$ & $\begin{array}{l}7.7 \\
+.7\end{array}$ & $\begin{array}{l}258 \\
+-1\end{array}$ & $\begin{array}{r}181170 \\
+<\end{array}$ & $\begin{array}{c}1851 \\
+/ .\end{array}$ & 24 & $\begin{array}{r}3.89 \\
+.-\end{array}$ & $\begin{array}{c}0.95 \\
+\quad-5\end{array}$ & 1992 & $\begin{array}{l}177126 \\
+t\end{array}$ & $\begin{array}{l}0.7 \\
+.7\end{array}$ & 1401 & 7.93 & 3577 & 47 & 0.8 & 56 \\
\hline & $10 \mathrm{Be}$ & 0 & $\begin{array}{l}+1-2 \\
17\end{array}$ & 49 & $\begin{array}{l}+1 . \\
1888\end{array}$ & 53 & 244 & 0.8 & 0.3 & 118 & 36204 & 346 & 9 & . & 0.1 & 113 & 17640 & 0.56 & 297 & 6.39 & 467 & 3 & 0.1 & 3 \\
\hline & & 200 & 1.13 & 1.07 & - & & & & & 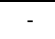 & - & & - & - & - & - & 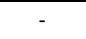 & - & & & 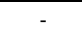 & - & - & - \\
\hline & & 400 & 1.14 & - & 1.25 & - & 1.23 & - & - & & - & - & & & - & & & -2.48 & 1.34 & - & - & - & - & - \\
\hline & 14.5 Bé & 0 & -1.26 & -1.22 & 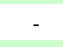 & -1.18 & -1.63 & -2.00 & -1.47 & & - & -1.54 & - &. & -2.25 & 2.13 & - & -2.06 & - & -3.36 & - & -1.29 & -2.10 & -4.43 \\
\hline$\simeq$ & & 200 & - & - & 1.31 & - & - & - & 1.13 & 3.46 & & 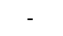 & - & 1.31 & 1.29 & -1.68 & - & - & & - & - & & & 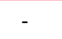 \\
\hline$\frac{\bar{z}}{\sigma}$ & & 400 & 1.07 & 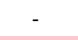 & 1.36 & - & 1.62 & & & 2.57 & 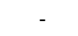 & 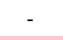 & -1.32 & 1.27 & & -2.22 & 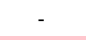 & - & - & - & -2.67 & - & - & \\
\hline$\Xi$ & 13.5 Bé & 0 & -1.47 & -1.57 & - & -1.19 & -1.36 & -3.60 & -1.53 & - & -1.51 & -1.59 & -1.24 & - & -2.46 & - & -1.21 & - & & - & -3.54 & -1.63 & -3.41 & -4.83 \\
\hline & & 200 & & - & - & - & & & 1.15 & - & & - & - & 1.29 & & & & & - & & & - & & \\
\hline & & 400 & 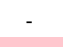 & 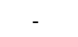 & 1.29 & - & 1.50 & - & 1.20 & & - & & - & & - & & - & -3.58 & - & -3.04 & - & - & - & - \\
\hline & 12.5 Bé & 0 & -2.31 & -2.08 & & -1.33 & -1.44 & -5.31 & -1.68 & & -1.85 & & -1.48 & & -2.76 & & -1.24 & & - & & -4.45 & -1.93 & -4.89 & -8.96 \\
\hline & & 200 & & 1.20 & - & -1.28 & & & & & & & 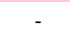 & & & - & & & 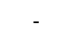 & & - & - & & \\
\hline & & 400 & 1.29 & 1.17 & & -1.17 & - & & & & . & & & & - & & & & - & & - & - & - & \\
\hline
\end{tabular}



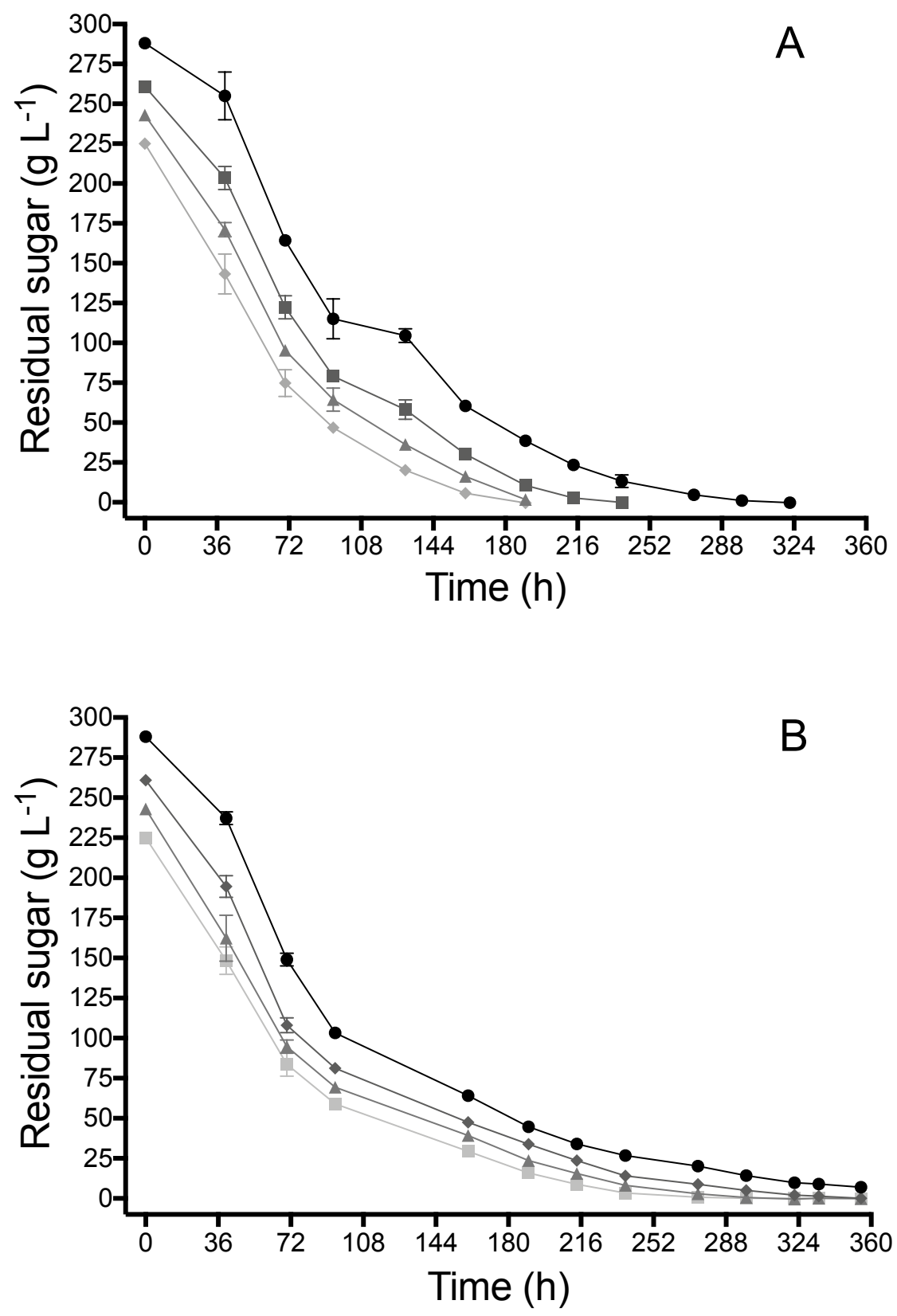

Figure 1. Gardner et al 


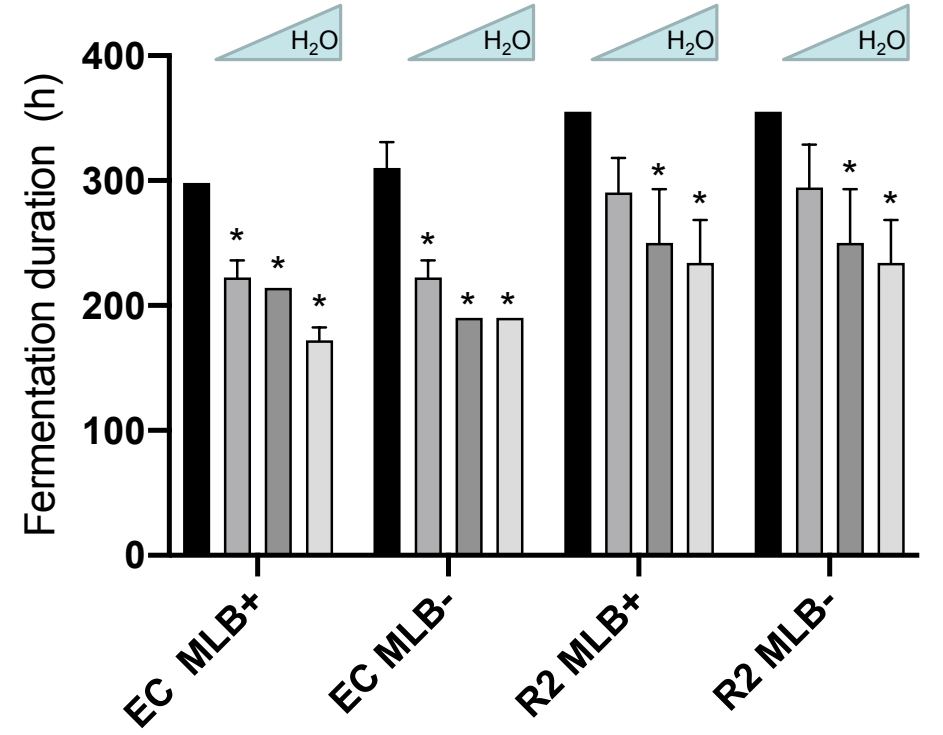

Figure 2. Gardner et al 


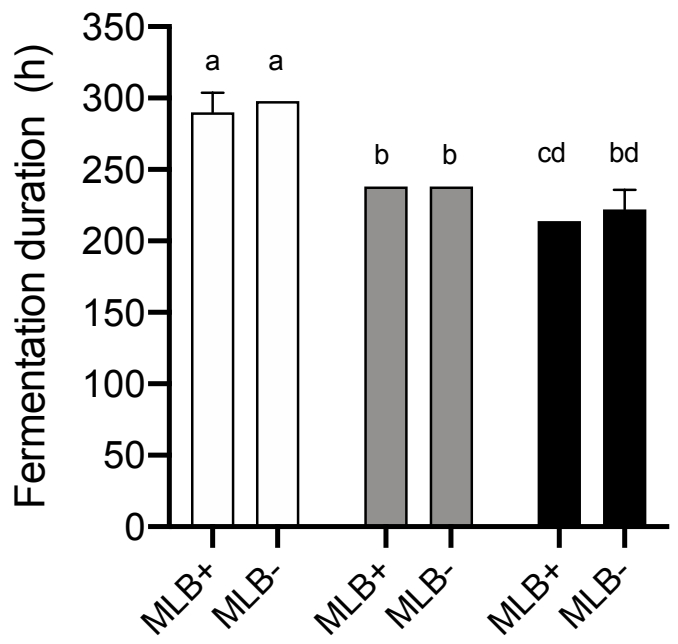

Figure 3. Gardner et al. 


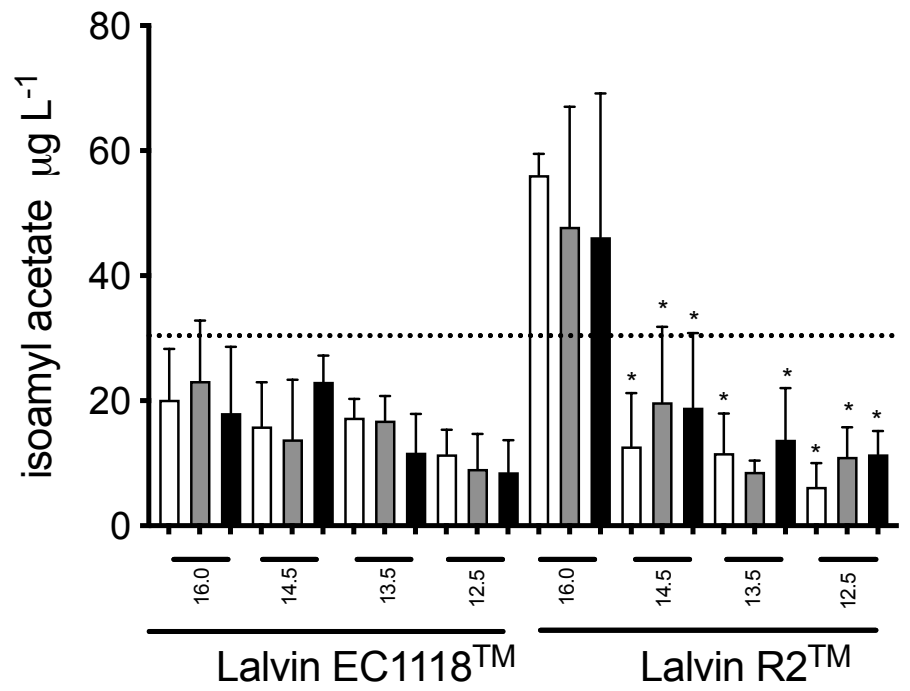

Figure 4. Gardner et al. 


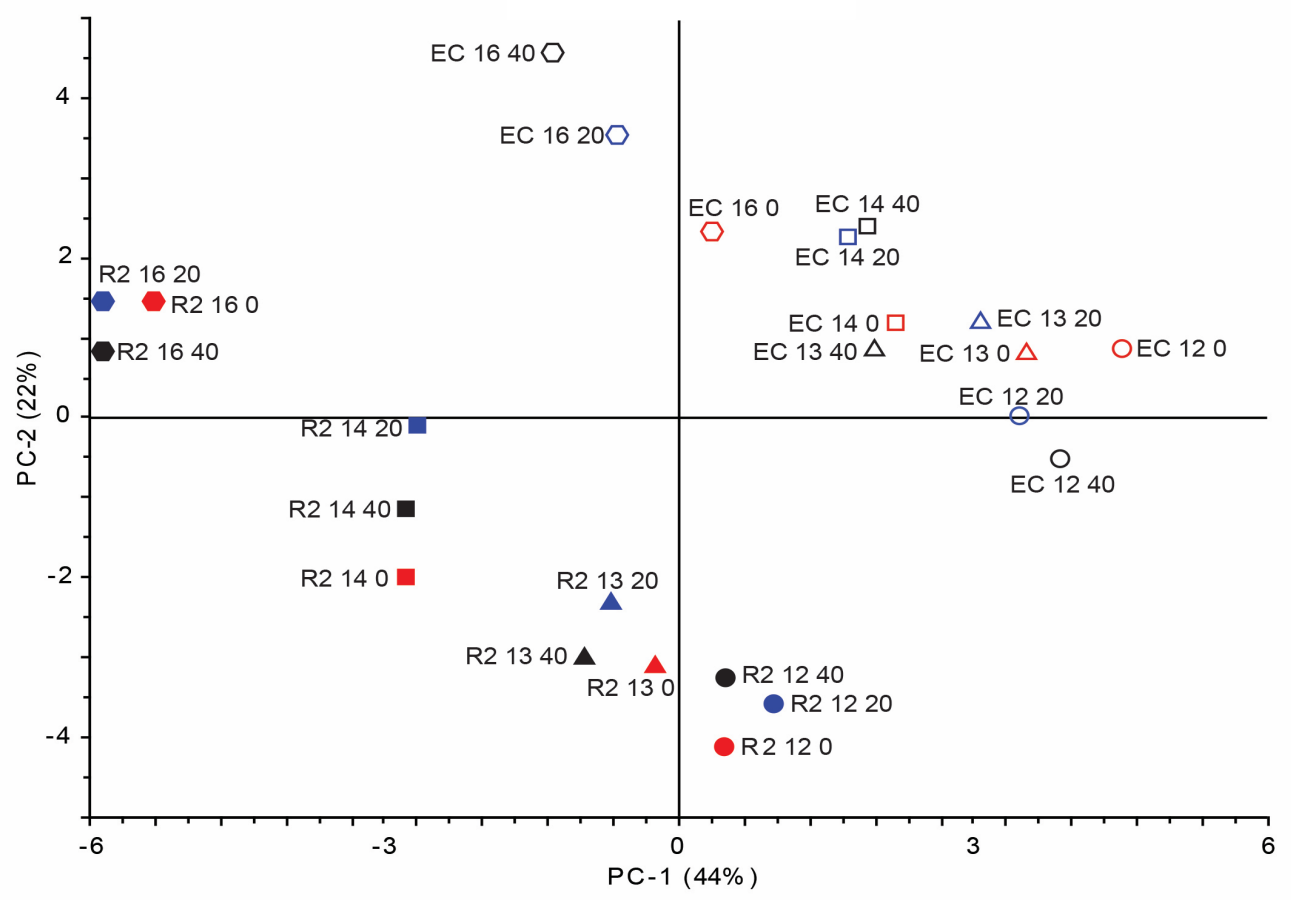

Figure 5. Gardner et al. 
Supplementary Table 1. Gardner et al.

\begin{tabular}{|c|c|c|c|c|}
\hline & Nutrient $\left(\mathrm{mg} \mathrm{L}^{-1}\right)$ & $\begin{array}{c}\text { Lalvin } \\
\text { EC1118 }^{\mathrm{TM}} \\
\end{array}$ & $\begin{array}{c}\text { Lalvin } \\
\text { R2 }^{\mathrm{TM}}\end{array}$ & \\
\hline \multirow[t]{3}{*}{16 Bé } & $\mathbf{0}$ & $2.3+/-0.1$ & $2.2+/-0.1$ & $\begin{array}{l}\not{0} \\
\mathscr{Q}\end{array}$ \\
\hline & 200 & $2.4+/-0.1$ & $2.2+/-0.1$ & 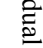 \\
\hline & 400 & $2.3+/-0.1$ & $2.2+/-0.1$ & 胥. \\
\hline \multirow[t]{3}{*}{ 14.5 Bé } & $\mathbf{0}$ & $2.1+/-0.1$ & $1.7+/-0.2$ & : \\
\hline & 200 & $1.4+/-0.1^{*}$ & $1.4+/-0.4$ & $\overparen{\sigma Q}$ \\
\hline & 400 & $1.0+/-0.9$ & $1.4+/-0.4$ & i \\
\hline \multirow[t]{3}{*}{ 13.5 Bé } & $\mathbf{0}$ & $1002+/-0$ & $1066+/-96$ & \\
\hline & 200 & $955+/-0^{*}$ & $955+/-0$ & \\
\hline & 400 & $955+/-0^{*}$ & $955+/-0$ & $\overline{\mathrm{E}}$ \\
\hline \multirow[t]{3}{*}{ 12.5 Bé } & $\mathbf{0}$ & $917+/-70$ & $874+/-70$ & હ \\
\hline & 200 & $834+/-0$ & $834+/-0$ & \\
\hline & 400 & $834+/-0$ & $834+/-0$ & \\
\hline
\end{tabular}


Supplementary Table 2. Volatile and major yeast metabolic compounds $\left(\mu \mathrm{g} \mathrm{L}^{-1}+\right.$-standard deviations) detected in final wines for all treatments except for those inoculated with lactic acid bacteria for malolactic fermentation The "no yeast controls" were also analysed, in most cases volatiles were below detection limits, where they were measured they were many magnitudes lower than fermented treatments and thus the data is not shown.

\begin{tabular}{|c|c|c|c|c|c|c|c|c|}
\hline$\mu g L^{-1}$ & EC1118 16Bé NO MLF- & EC1118 16Bé N200 MLF- & EC1118 16Bé N400 MLF- & EC1118 14.5Bé NO MLF- & EC1118 14.5Bé N200 MLF- & EC1118 14.5Bé N400 MLF- & EC1118 13.5Bé N0 MLF- & EC1118 13.5Bé N200 MLF- \\
\hline Ethyl acetate & $1768.95+/-228.13$ & $1980.56+/-284.26$ & $2043.34+/-146.59$ & $1603.35+/-188.62$ & $1744.16+/-70.35$ & $1587.54+/-166.87$ & $1379.49+/-61.82$ & $1313.78+/-197.82$ \\
\hline Ethyl propanoate & $12.73+/-0.84$ & $11.86+/-1.92$ & $14.16+/-1.24$ & $21.01+/-13.13$ & $20.89+/-14.62$ & $19.43+/-4.75$ & $22.7+/-12.81$ & $16.98+/-4.19$ \\
\hline Ethyl isobutyrate & $0.42+/-0.17$ & $0.42+/-0.1$ & $0.49+/-0.13$ & $0.41+/-0.03$ & $0.45+/-0.03$ & $0.47+/-0.16$ & $0.42+/-0.04$ & $0.55+/-0.12$ \\
\hline Isobutyl acetate & $0.35+/-0.09$ & $0.4+/-0.08$ & $0.46+/-0.02$ & $0.3+/-0.09$ & $0.3+/-0.06$ & $0.34+/-0.11$ & $0.27+/-0.04$ & $0.3+/-0.03$ \\
\hline Ethyl butanoate & $6.95+/-0.82$ & $7.28+/-0.59$ & $7.58+/-0.63$ & $6.82+/-1.67$ & $7.44+/-1.86$ & $7.67+/-1.14$ & $6.35+/-0.91$ & $6.35+/-0.82$ \\
\hline Ethyl 2-methylbutyrate & $1.35+/-0.54$ & $1.29+/-0.3$ & $1.51+/-0.52$ & $1.2+/-0.09$ & $1.25+/-0.09$ & $1.38+/-0.49$ & $1.1+/-0.14$ & $1.54+/-0.41$ \\
\hline Ethyl isovalerate & $0.1+/-0.03$ & $0.09+/-0.02$ & $0.11+/-0.03$ & $0.08+/-0.01$ & $0.08+/-0.01$ & $0.09+/-0.03$ & $0.08+/-0.01$ & $0.1+/-0.03$ \\
\hline Isobutanol & $125698.23+/-53324.07$ & $126726.05+/-69190.63$ & $142155.4+/-70298.6$ & $114285.41+/-52723.51$ & $119149.25+/-79073.22$ & $107815.65+/-58647.55$ & $72809.37+/-5711.94$ & $102496.48+/-55216.01$ \\
\hline Isoamyl acetate & $20.15+/-8.12$ & $23.14+/-9.72$ & $18.03+/-10.58$ & $15.93+/-7.04$ & $13.81+/-9.58$ & $23.01+/-4.24$ & $17.28+/-2.99$ & $16.83+/-3.91$ \\
\hline Methyl hexanoate & $4.15+/-2.54$ & $3.14+/-1.68$ & $8.66+/-7.51$ & $6.71+/-8.45$ & $5.76+/-7.38$ & $7.6+/-5.4$ & $6.1+/-4.71$ & $9.95+/-2.6$ \\
\hline Hexyl acetate & $0.34+/-0.07$ & $0.44+/-0.17$ & $0.38+/-0.1$ & $0.3+/-0.11$ & $0.35+/-0.09$ & $0.29+/-0.04$ & $0.28+/-0.09$ & $0.26+/-0.09$ \\
\hline 4-Methyl-1-pentanol & $649.6+/-21.64$ & $722.02+/-37.93$ & $790.12+/-14.93$ & $447.2+/-9.04$ & $473.06+/-9.96$ & $495.03+/-23.85$ & $363.61+/-5.55$ & $368.98+/-16.36$ \\
\hline 3-Methyl-1-pentanol & $217.43+/-16.3$ & $237.48+/-22.86$ & $268.57+/-17.62$ & $121.68+/-5.33$ & $115.04+/-3.38$ & $130.52+/-9.03$ & $89.73+/-3.43$ & $90.07+/-15.27$ \\
\hline Ethyl lactate & $3.91+/-0.24$ & $4.11+/-0.13$ & $4.04+/-0.38$ & $3.86+/-0.37$ & $3.74+/-0.3$ & $3.96+/-0.45$ & $3.43+/-0.32$ & $3.61+/-0.21$ \\
\hline Methyl octanoate & $5.9+/-3.54$ & $5.11+/-2.51$ & $10.7+/-7.96$ & $5.39+/-4.55$ & $4.87+/-4.03$ & $7.89+/-5.24$ & $7.22+/-7.1$ & $11.95+/-2.74$ \\
\hline Acetic acid & $260.52+/-178.21$ & $303.34+/-319.91$ & $198.02+/-108.03$ & $148.26+/-118.28$ & $193.05+/-141.69$ & $71.51+/-17.55$ & $116.21+/-51.44$ & $111.44+/-35.15$ \\
\hline Ethyl nonanoate & $0.01+/-0$ & $0.01+1-0$ & $0.01+/-0$ & $0.01+/-0$ & $0.01+/-0$ & $0.01+/-0$ & $0.01+/-0$ & $0.01+/-0$ \\
\hline Isobutyric acid & $601.36+/-90.17$ & 768.11+/-131.04 & $1010.84+/-207.19$ & $700.81+/-192.6$ & $798.26+/-189.21$ & $764.09+/-261.11$ & $698.22+/-70.03$ & $741.69+/-153.17$ \\
\hline Methyl decanoate & $0.65+/-0.46$ & $0.66+/-0.4$ & $1.88+/-1.7$ & $0.5+/-0.36$ & $0.5+/-0.31$ & $0.74+/-0.52$ & $0.53+/-0.42$ & $0.88+/-0.19$ \\
\hline Butanoic acid & $894.96+/-148.87$ & $1024.72+/-176.33$ & $1191.96+/-133.89$ & $854.41+/-379.16$ & $1032.4+/-66.82$ & $997.52+/-153.55$ & $784.94+/-65.09$ & $919.23+/-64.29$ \\
\hline Ethyl decanoate & $20.38+/-3.33$ & $27.18+/-7.16$ & $37.51+/-17.06$ & $15.01+/-5.77$ & $19.04+/-9.05$ & $15.13+/-3.2$ & $12.05+/-4.42$ & $12.2+/-3.04$ \\
\hline Isoamyl octanoate & $0.02+/-0$ & $0.02+/-0$ & $0.02+1-0.01$ & $0.01+/-0$ & $0.01+/-0.01$ & $0.01+/-0$ & $0.01+/-0$ & $0.01+1-0$ \\
\hline Isovaleric acid & $2228.51+/-348.56$ & $2438.44+/-432.24$ & $3020.47+/-346.93$ & $2327.57+/-1407.94$ & $2293.53+/-717.66$ & $2346.64+/-158.01$ & $1809.91+/-608.65$ & $2012.49+/-121.89$ \\
\hline 2-Methylbutanoic acid & $2795.75+/-548.33$ & $2961.35+/-592.74$ & $3548.08+/-403.09$ & $2832.92+/-1518.63$ & $2864.7+/-831.53$ & $2931.88+/-279.69$ & $2106.96+/-628.69$ & $2455.78+/-132.22$ \\
\hline Methionol & $1297.26+/-43.38$ & $1546.55+/-238.25$ & $1516.77+/-344.78$ & $1166.77+/-343.26$ & $1367.15+/-374.39$ & $1157.83+/-137.46$ & $1064.46+/-218.79$ & $1251.15+/-179.04$ \\
\hline 2-Phenylethyl acetate & $4.83+/-1.64$ & $5.89+/-1.44$ & $6.01+/-1.13$ & $2.98+/-0.93$ & $3.87+/-0.98$ & $4.03+/-0.72$ & $2.24+/-1.04$ & $2.45+/-0.73$ \\
\hline Ethyl dodecanoate & $0.12+/-0.01$ & $0.16+/-0.03$ & $0.21+/-0.1$ & $0.1+/-0.03$ & $0.11+/-0.05$ & $0.1+/-0.01$ & $0.09+/-0.03$ & $0.09+/-0.03$ \\
\hline Hexanoic acid & $6107.29+/-384.45$ & $8509.74+/-587.18$ & $8339.73+/-1358.46$ & $6905.94+/-238.16$ & $8682.74+/-1594.91$ & $8617.89+/-547.51$ & $6863.48+/-442.99$ & $8360.89+/-518.06$ \\
\hline Benzyl alcohol & $37.02+/-4.86$ & $38.51+/-4.93$ & $38.88+/-5.6$ & $29.38+1-6.98$ & $32.3+/-8.07$ & $31.37+/-3.79$ & $29+/-5.99$ & $29.38+/-2.53$ \\
\hline 2-Phenylethyl propanoate & $0.19+/-0.04$ & $0.2+/-0.04$ & $0.22+/-0.01$ & $0.22+/-0.06$ & $0.24+/-0.07$ & $0.29+/-0.03$ & $0.22+/-0.02$ & $0.22+/-0.04$ \\
\hline Octanoic Acid & $222.21+/-49.42$ & $499.96+/-99.2$ & $695.12+/-382.86$ & $263.23+/-89.08$ & $511.93+/-187.57$ & $604.24+/-137.04$ & $318.7+/-75.73$ & $444.78+/-86.82$ \\
\hline 2-Methoxy-4-vinylphenol & $2544.42+/-787.45$ & $2228.15+/-348.6$ & $1535.06+/-149.52$ & $2028.07+/-591.07$ & $1725.79+/-647.29$ & $1431.93+/-492.53$ & $2250.4+/-484.39$ & $1898.33+/-242.44$ \\
\hline 4-vinylphenol & $4102.24+/-1418.58$ & $4055.88+/-919.13$ & $3310.32+/-676.09$ & $3522.71+/-1096.67$ & $3773.27+/-1381.07$ & $3608.69+/-867.58$ & $4132.05+/-1083.36$ & $4253.17+/-673.16$ \\
\hline Isoamyl alcohol $(1 / 100)$ & $145139.95+/-13654.68$ & $144590.34+/-14025.96$ & $143960.98+/-11148.68$ & $129787.17+/-19120.85$ & $129635.03+/-18549.35$ & $132704.76+/-19779.9$ & $118268.24+/-16518.57$ & $120678.32+/-17202.09$ \\
\hline Ethyl hexanoate $(1 / 100)$ & $11.48+/-3.02$ & $11.58+/-2.77$ & $11.47+/-3.27$ & $11.81+/-4.88$ & $12.39+/-5.06$ & $12.34+/-3.64$ & $9.8+/-5.28$ & $10.15+/-1.98$ \\
\hline Ethyl octanoate $(1 / 100)$ & $3.28+/-1.89$ & $3.45+/-1.66$ & $3.23+/-1.35$ & $2.4+/-0.57$ & $2.82+/-0.56$ & $2.34+/-1.08$ & $1.91+/-0.74$ & $2.33+/-1.03$ \\
\hline Phenylethyl alcohol $(1 / 100)$ & $171614.28+/-17567.67$ & $180885.68+/-23730.72$ & $198504.71+/-33572.19$ & $119530.39+/-7971.31$ & $123171.42+/-23395.96$ & $136900.72+/-6162.4$ & $99590.5+/-17126.72$ & $102239.13+/-17127.63$ \\
\hline \multirow{7}{*}{$\begin{array}{c}\mathbf{g ~ L}^{-1} \\
\text { Malic Acid (HPLC) } \\
\text { Succinic Acid (HPLC) } \\
\text { Lactic Acid (HPLC) } \\
\text { Glycerol (HPLC) } \\
\text { Acetaldehyde (HPLC) }\end{array}$} & EC1118 16Bé N0 MLF- & EC1118 16Bé N200 MLF- & EC1118 16Bé N400 MLF- & EC1118 14.5Bé N0 MLF- & EC1118 14.5Bé N200 MLF- & EC1118 14.5Bé N400 MLF- & EC1118 13.5Bé N0 MLF- & EC1118 13.5Bé N200 N \\
\hline & $3.38+/-0.05$ & $3.37+/-0.07$ & $3.36+/-0.07$ & $3.11+/-0.05$ & $3.1+/-0.01$ & $3.16+/-0.05$ & $2.88+/-0.03$ & $2.92+/-0.04$ \\
\hline & $2.68+/-0.11$ & $2.72+/-0.02$ & $2.8+/-0.02$ & $2.2+/-0.1$ & $2.25+/-0.13$ & $2.31+/-0.06$ & $1.97+/-0.1$ & $2.07+/-0.04$ \\
\hline & $1.1+/-0.14$ & $0.67+/-0.6$ & $1.13+/-0.04$ & $0.72+/-0.63$ & $0.65+/-0.56$ & $0.74+/-0.65$ & $0+1-0$ & $0.36+/-0.62$ \\
\hline & $7.77+/-0.01$ & $7.77+/-0.01$ & $7.79+/-0.1$ & $6.73+/-0.05$ & $6.76+/-0.04$ & $6.81+/-0.07$ & $6.16+/-0.15$ & $6.15+/-0.12$ \\
\hline & $0.33+/-0.01$ & $0.45+/-0.04$ & $0.45+/-0.03$ & $0.27+/-0.01$ & $0.37+/-0.02$ & $0.4+/-0.08$ & $0.21+/-0.03$ & $0.27+/-0.03$ \\
\hline & $120.83+/-0.29$ & $120.95+/-0.56$ & $119.98+/-0.95$ & $108.75+/-1.45$ & $108.18+/-1.11$ & $107.86+/-0.49$ & $100.83+/-0.28$ & $100.17+/-1.02$ \\
\hline
\end{tabular}




\begin{tabular}{|c|c|c|c|c|c|c|c|c|c|}
\hline EC1118 13.5Bé N400 MLF- & EC1118 12.5Bé N0 MLF- & EC1118 12.5Bé N200 MLF- & EC1118 12.5Bé N400 MLF- & R2 16Bé N0 MLF- & R2 16Bé N200 MLF- & R2 16Bé N400 MLF- & R2 14.5Bé N0 MLF- & R2 14.5Bé N200 MLF- & R2 14.5Bé N400 MLF- \\
\hline $1568.33+/-133.61$ & $1205.21+/-56.43$ & $1250.56+/-52.63$ & $1158.48+/-31.09$ & $1942.12+/-53.77$ & $2129.91+/-257.04$ & $1994.87+/-151.87$ & $1641.65+/-133.15$ & $1708.91+/-260.32$ & $1655.26+/-244.21$ \\
\hline $19.01+/-10.73$ & $18.86+/-3.77$ & $11.53+/-2.38$ & $13.12+/-4.6$ & $7.88+/-0.73$ & $7.55+/-0.12$ & $7.22+/-0.59$ & $8.55+/-1.43$ & $6.95+/-4.78$ & $9.01+/-1.72$ \\
\hline $0.61+/-0.19$ & $0.4+/-0.12$ & $0.38+/-0.12$ & $0.43+/-0.16$ & $0.87+/-0.33$ & $0.8+/-0.3$ & $0.82+/-0.3$ & $0.62+/-0.24$ & $0.61+/-0.29$ & $0.71+/-0.23$ \\
\hline $0.29+/-0.09$ & $0.28+/-0.01$ & $0.21+/-0.06$ & $0.25+/-0.03$ & $0.95+/-0.08$ & $1.03+/-0.05$ & $0.92+/-0.12$ & $0.42+/-0.02$ & $0.54+/-0.1$ & $0.45+/-0.02$ \\
\hline $7.1+/-1.48$ & $5.54+/-0.46$ & $5+/-0.36$ & $5.26+/-0.81$ & $7.76+/-0.37$ & $7.5+/-0.14$ & $7.21+/-0.23$ & $5.29+/-0.4$ & $5.98+/-0.18$ & $5.93+/-0.5$ \\
\hline $1.63+/-0.68$ & $0.88+/-0.31$ & $0.83+/-0.29$ & $0.97+/-0.4$ & $1.41+/-0.56$ & $1.19+/-0.38$ & $1.27+/-0.45$ & $1.21+/-0.5$ & $1.27+/-0.58$ & $1.33+/-0.48$ \\
\hline $0.11+/-0.05$ & $0.07+/-0.02$ & $0.06+/-0.02$ & $0.07+/-0.03$ & $0.15+/-0.05$ & $0.13+/-0.03$ & $0.13+/-0.04$ & $0.12+/-0.04$ & $0.13+/-0.05$ & $0.14+/-0.04$ \\
\hline $73651.95+/-8401.62$ & $66295.94+/-7509.4$ & $58513.27+/-4741.69$ & $64253.44+/-7178.29$ & $247540.7+/-142527.18$ & $313769.05+/-118089.39$ & $237953.24+/-130659.29$ & $194559.8+/-84559.05$ & $196773.96+/-78056.01$ & $194353.67+/-82554.99$ \\
\hline $11.69+/-6.22$ & $11.44+/-3.93$ & $9.08+/-5.61$ & $8.56+/-5.15$ & $56.13+/-3.4$ & $47.82+/-19.22$ & $46.15+/-23.04$ & $12.67+/-8.57$ & $19.8+/-12.04$ & $18.93+/-11.93$ \\
\hline $7.15+/-8.83$ & $10.49+/-0.72$ & $1.58+/-0.89$ & $5.56+/-4.86$ & $4.15+/-3.05$ & $2.09+/-1.13$ & $1.57+/-0.28$ & $1.31+/-0.39$ & $1.91+/-1.18$ & $2.03+/-1.48$ \\
\hline $0.31+/-0.1$ & $0.26+/-0.06$ & $0.26+/-0.03$ & $0.21+/-0.05$ & $0.83+/-0.1$ & $0.84+/-0.04$ & $0.73+/-0.21$ & $0.4+/-0.13$ & $0.49+/-0.23$ & $0.42+/-0.08$ \\
\hline $390.47+/-9.9$ & $296.61+/-32.92$ & $297.64+/-6.29$ & $296.47+/-13.24$ & $1647.66+/-49.25$ & $1760.51+/-17.89$ & $1720.51+/-116.86$ & $1354.75+/-25.4$ & $1385.13+/-12.14$ & $1444.98+/-83.83$ \\
\hline $98.63+/-2.63$ & $67.27+/-9.79$ & $66.31+/-6.29$ & $65.56+/-5.57$ & $281.55+/-17.25$ & $317.9+/-8.22$ & $320.41+/-23.79$ & $223.64+/-9.12$ & $241.96+/-13.39$ & $258.23+/-20.76$ \\
\hline $3.49+/-0.24$ & $3.12+/-0.46$ & $3+/-0.16$ & $2.85+/-0.19$ & $3.89+/-0.19$ & $4.26+/-0.46$ & $4.32+/-0.36$ & $3.57+/-0.26$ & $4.66+/-0.73$ & $4.53+/-0.39$ \\
\hline $6.39+/-5.19$ & $11.59+/-2.06$ & $2.31+/-0.99$ & $6.03+/-3.86$ & $7.93+/-6.39$ & $4.32+/-2.49$ & $3.52+/-0.36$ & $2.36+/-0.79$ & $4.61+/-0.53$ & $3.02+/-1.64$ \\
\hline $136.38+/-34.79$ & $135.52+/-65.15$ & $65.56+/-24.14$ & $58.41+/-22.14$ & $3577.54+/-467.55$ & $3720.28+/-1332.34$ & $4509.36+/-951.82$ & $3376.53+/-2631.06$ & $1802.53+/-1552.1$ & $1262.97+/-527.08$ \\
\hline $0.01+/-0$ & $0.01+1-0$ & $0.01+/-0$ & $0.01+/-0$ & $0.02+/-0.01$ & $0.01+/-0$ & $0.02+/-0.01$ & $0.02+/-0$ & $0.02+/-0.01$ & $0.02+/-0.01$ \\
\hline $1072.06+/-410.75$ & $501.28+/-123.94$ & $676.59+/-78.96$ & $766.04+/-128.2$ & $1401+/-297.78$ & $1403.51+/-83.35$ & $1880.81+/-231.93$ & $1079.8+/-284.21$ & $1149.45+/-146.28$ & $1357.95+/-167.97$ \\
\hline $0.48+/-0.15$ & $0.77+/-0.32$ & $0.3+/-0.09$ & $0.47+/-0.27$ & $0.7+/-0.56$ & $0.35+/-0.21$ & $0.28+/-0.06$ & $0.34+/-0.13$ & $0.35+/-0.11$ & $0.24+/-0.08$ \\
\hline $1300.59+/-404.4$ & $710.18+/-54.43$ & $859.23+/-119.3$ & $960.62+/-80.55$ & $1018.64+/-244.39$ & $997+/-45.1$ & $1248.35+/-187.2$ & $624.25+/-64.14$ & $797.81+/-27.46$ & $1008.93+/-76.64$ \\
\hline $15.32+/-7.94$ & $10.88+/-4.8$ & $15.09+/-5.58$ & $11.8+/-5.97$ & $24.33+/-8.98$ & $21.82+/-5.97$ & $21.9+/-8.15$ & $26.4+/-7.58$ & $19.03+/-3.48$ & $15.42+/-2.73$ \\
\hline $0.01+/-0.01$ & $0.01+/-0$ & $0.02+/-0.01$ & $0.01+/-0$ & $0.03+/-0.01$ & $0.04+/-0.01$ & $0.04+/-0.01$ & $0.03+/-0$ & $0.04+/-0$ & $0.03+/-0.01$ \\
\hline $2598.28+/-1164.6$ & $1390.76+/-83$ & $1513.8+/-153.63$ & $1806.54+/-270.41$ & $2859.32+/-749.76$ & $2859.86+/-240.62$ & $3490.77+/-733.98$ & $2477.73+/-341.56$ & $2658.41+/-409.66$ & $3436.71+/-380.5$ \\
\hline $3137.64+/-1446.78$ & $1529.9+/-81.17$ & $1674.71+/-144.82$ & $1974.25+/-269.27$ & $2640.71+/-679.41$ & $2562.15+/-302.89$ & $3199.1+/-762.2$ & $2221.78+/-292.6$ & $2358.32+/-481.97$ & $3072.23+/-268.73$ \\
\hline $1120.01+/-191.07$ & $723.3+/-157.03$ & $776.11+/-153.28$ & $745.96+1-231.42$ & $1991.76+/-113.23$ & $1379.25+/-240.34$ & $1134.22+/-273.04$ & $4247.53+/-1437.01$ & $2528.13+/-1119.24$ & $1916.6+/-739.24$ \\
\hline $2.99+/-1.03$ & $1.69+/-0.59$ & $2.07+/-0.43$ & $1.82+/-0.44$ & $7.9+/-0.84$ & $9+/-2.18$ & $8.92+/-1.02$ & $3.94+/-1.28$ & $5.81+/-1.46$ & $5.72+/-1.97$ \\
\hline $0.11+/-0.05$ & $0.09+/-0.02$ & $0.13+/-0.02$ & $0.1+/-0.03$ & $0.14+/-0.03$ & $0.13+/-0.02$ & $0.13+/-0.03$ & $0.15+/-0.05$ & $0.14+/-0$ & $0.12+/-0.02$ \\
\hline $9327.58+/-1629.67$ & $6646.72+/-930.25$ & $9370.06+/-522.92$ & $9103.97+/-1827.25$ & $5974.48+/-1888.83$ & $6126.52+/-273.99$ & $7453.07+/-1170$ & $4736.21+/-78.19$ & $6208.12+\mid-715.1$ & $6460.09+/-138.62$ \\
\hline $30.36+/-4.77$ & $24.6+/-4.44$ & $26.57+/-6.65$ & $25.25+/-5.73$ & $47.35+/-3.07$ & $46.62+/-7.32$ & $46.4+/-4.57$ & $36.79+/-5.4$ & $37.32+/-3.1$ & $38.04+/-5.44$ \\
\hline $0.21+/-0.05$ & $0.17+/-0.06$ & $0.14+/-0.05$ & $0.15+/-0.04$ & $0.13+/-0.02$ & $0.1+/-0.01$ & $0.11+/-0.02$ & $0.1+/-0.02$ & $0.13+/-0.04$ & $0.14+/-0.04$ \\
\hline $509.41+/-320.5$ & $264.74+/-73.69$ & $538.08+/-59.44$ & $568.55+/-152.45$ & $258.25+/-117.97$ & $298.72+/-62.54$ & $399.42+/-40.03$ & $156.35+/-69.83$ & $541.51+/-355.49$ & $401.99+/-84.13$ \\
\hline $1400.24+/-490.26$ & $2253.32+/-431.19$ & $1661.03+/-214.1$ & $1311.9+/-352.09$ & $1851.68+/-346$ & $1761.63+/-444.81$ & $1561.58+/-253.17$ & $1202.87+/-95.23$ & $1743.63+/-311.75$ & $1177.93+/-398.07$ \\
\hline $3911.38+/-770.25$ & $4057.1+/-1065.72$ & 4091.55+/-1012.43 & $3905.82+/-671.62$ & $3138+/-587.95$ & $3559+/-1163.8$ & $3427.97+/-761.39$ & $2436.8+/-263.34$ & $4344.01+/-1006.38$ & $3582.77+/-656.98$ \\
\hline $118709.04+/-12145.76$ & $112805.12+/-10786.68$ & $109208.75+/-11316.3$ & $107728.25+/-9857.3$ & $177126.62+/-17640.29$ & $178202.97+/-15471.91$ & $179763.43+/-22098.7$ & $160413.7+/-17426.88$ & $159408.74+/-12613.05$ & $163663.85+/-17344.57$ \\
\hline $9.98+/-4.75$ & $10.57+/-3.97$ & $7.89+/-2.22$ & $6.58+/-1.46$ & $10.17+/-0.89$ & $9.42+/-1.08$ & $8.9+/-2.31$ & $9.51+/-2.33$ & $8.89+/-1.99$ & $8.49+/-1.04$ \\
\hline $2.03+/-0.8$ & $2.45+/-1.76$ & $2.31+/-1.13$ & $1.64+/-0.79$ & $3.41+/-0.64$ & $3.71+/-1.08$ & $3.1+/-1.38$ & $3.37+/-1.62$ & $2.97+/-1.03$ & $2.49+/-0.74$ \\
\hline $111263.29+/-18489.68$ & $84947.28+/-12437.26$ & $92454.09+/-17194.55$ & $94762.59+/-18071.24$ & $181170.82+/-36204.95$ & $184074.43+/-23929.88$ & $193482.33+/-60301.19$ & $156057.4+/-41463.33$ & $155827.85+/-30786.41$ & $173978.51+/-31969.46$ \\
\hline EC1118 13.5Bé N400 MLF- & EC1118 12.5Bé N0 MLF- & EC1118 12.5Bé N200 MLF- & EC1118 12.5Bé N400 MLF- & R2 16Bé N0 MLF- & R2 16Bé N200 MLF- & R2 16Bé N400 MLF- & R2 14.5Bé N0 MLF- & R2 14.5Bé N200 MLF- & R2 14.5Bé N400 MLF- \\
\hline $2.93+/-0.04$ & $2.64+/-0.04$ & $2.66+/-0.04$ & $2.67+/-0.05$ & $2.84+/-0.04$ & $2.81+/-0.03$ & $2.87+/-0.05$ & $2.63+/-0.03$ & $2.6+/-0.03$ & $2.63+/-0.02$ \\
\hline $2.1+/-0.14$ & $1.8+/-0.03$ & $1.96+/-0.02$ & $1.96+/-0.07$ & $3.22+/-0.03$ & 3.75 & $3.54+/-0.1$ & $1-0.1$ & 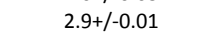 & $3.02+/-0.07$ \\
\hline $0.7+/-0.61$ & $0.69+/-0.6$ & $0.63+/-0.55$ & $0.29+/-0.5$ & $1+/-0.02$ & $0.3+/-0.51$ & $0.27+/-0.47$ & $0.65+/-0.56$ & $0.82+/-0.03$ & $0.53+/-0.46$ \\
\hline $6.22+/-0.05$ & $5.75+/-0.03$ & $5.77+/-0.01$ & $5.73+/-0.06$ & $7.87+/-0.04$ & $7.98+/-0.04$ & $7.98+/-0.08$ & $7.12+/-0.06$ & $7.08+/-0.09$ & $7.11+/-0.05$ \\
\hline $0.26+/-0.02$ & $0.16+/-0.04$ & 0.2 & -0.03 & $0.12+/-0.01$ & $0.15+/-0.06$ & $0.11+/-0.01$ & $0.24+/-0.07$ & $0.27+/-0.03$ & $0.24+/-0.01$ \\
\hline $101.14+/-0.59$ & $92+/-0.21$ & $92.65+/-0.27$ & $91.95+/-0.31$ & $122.54+/-0.27$ & $122.35+/-0.49$ & $122.24+/-0.46$ & $109.37+/-0.47$ & $109.05+/-0.7$ & $109.07+/-0.3$ \\
\hline
\end{tabular}




\begin{tabular}{|c|c|c|c|c|c|c|c|c|c|}
\hline R2 13.5Bé N0 MLF- & R2 13.5Bé N200 MLF- & R2 13.5Bé N400 MLF- & R2 12.5Bé NO MLF- & R2 12.5Bé N200 MLF- & R2 12.5Bé N400 MLF- & NO Yeast 16 Be NO MLF & 10 Yeast $14.5 \mathrm{Be}$ NO MLF & OO Yeast 13.5 Be NO MLF- & $\mathrm{O}$ Yeast 12.5 Be NO MLF- \\
\hline $1630.23+/-152.5$ & $1531.15+/-74.51$ & $1470.44+/-51.87$ & $1459.07+/-67.13$ & $1140.58+/-52.74$ & $1246.44+/-52.2$ & $89.37+/-66.58$ & $93.58+/-87.88$ & $119.35+/-92.89$ & $114.08+/-81.59$ \\
\hline $14.52+/-4.98$ & $15.2+/-6.3$ & $15.11+/-5.73$ & $15.53+/-9.75$ & $12.45+/-0.98$ & $13.16+/-2.52$ & $0.72+/-0.67$ & $1.27+/-0.61$ & $0.88+/-0.72$ & $0.89+/-0.74$ \\
\hline $0.76+/-0.33$ & $0.72+/-0.28$ & $0.74+/-0.15$ & $0.89+/-0.29$ & $0.67+/-0.17$ & $0.7+/-0.17$ & $0.01+/-0.01$ & $0.01+/-0.01$ & $0.01+/-0.01$ & $0.01+/-0.01$ \\
\hline $0.39+/-0.09$ & $0.36+/-0.02$ & $0.37+/-0.03$ & $0.34+/-0.02$ & $0.3+/-0.01$ & $0.25+/-0.03$ & $0.03+/-0.01$ & $0.05+/-0.04$ & $0.06+/-0.02$ & $0.04+/-0$ \\
\hline $5.08+/-0.43$ & $5.83+/-0.46$ & $6.09+/-0.25$ & $4.61+/-0.58$ & $4.79+/-0.26$ & $5.21+/-0.48$ & $0.14+/-0.14$ & $0.16+/-0.19$ & $0.21+/-0.19$ & $0.2+/-0.17$ \\
\hline $1.62+/-0.76$ & $1.54+/-0.76$ & $1.53+/-0.32$ & $1.68+/-0.51$ & $1.33+/-0.41$ & $1.43+/-0.37$ & $0+1-0$ & $0+/-0$ & $0+/-0$ & $0.01+/-0$ \\
\hline $0.15+/-0.05$ & $0.14+/-0.05$ & $0.14+/-0.02$ & $0.14+/-0.04$ & $0.13+/-0.03$ & $0.13+/-0.03$ & $0+1-0$ & $0+1-0$ & $0+1-0$ & $0+/-0$ \\
\hline $137977.49+/-21045.73$ & $129447.78+/-14980.08$ & $170366.03+/-65187.59$ & $212565.18+/-147448.1$ & $166882.56+/-91445.01$ & $110906.56+/-5436.18$ & $465.75+/-501.93$ & $1327.85+/-1135.74$ & $257.81+/-146.18$ & $575.02+/-411.96$ \\
\hline $11.63+/-6.33$ & $8.66+/-1.77$ & $13.78+/-8.27$ & $6.26+/-3.76$ & $11.02+/-4.75$ & $11.42+/-3.78$ & $0.41+/-0.33$ & $0.81+/-1.01$ & $0.66+/-0.61$ & $0.78+/-0.93$ \\
\hline $7.71+/-2$ & $5.99+/-1.5$ & $2.49+/-1.32$ & $5.53+/-3.86$ & $3.97+/-2.57$ & $3.25+/-1.55$ & $0.03+/-0.03$ & $0.04+/-0.02$ & $0.04+/-0.01$ & $0.03+/-0.02$ \\
\hline $0.24+/-0.08$ & $0.32+/-0.11$ & $0.25+/-0.03$ & $0.17+/-0.08$ & $0.2+/-0.05$ & $0.23+/-0.04$ & $0+/-0$ & $0+1-0$ & $0+/-0$ & $0.01+/-0$ \\
\hline $1051.02+/-36.01$ & $1127+/-59.95$ & $1027.66+/-86.25$ & $791.25+/-86.51$ & $952.06+/-50.04$ & $929.42+/-56.41$ & $8.24+/-6.16$ & $9.47+/-9.14$ & $9.48+/-5.83$ & $9.96+/-6.24$ \\
\hline $191.93+/-22.66$ & $193.49+/-6.77$ & $178.27+/-17.08$ & $121.69+/-15.4$ & $144.15+/-3.51$ & $157.01+/-6.9$ & $1.21+/-0.92$ & $1.68+/-1.35$ & $1.5+/-0.79$ & $1.4+/-1.09$ \\
\hline $3.1+/-0.11$ & $3.98+/-0.61$ & $3.85+/-0.44$ & $3.45+/-1.11$ & $3.85+/-0.33$ & $3.83+/-0.41$ & $0.28+/-0.04$ & $0.27+/-0.01$ & $0.3+/-0.03$ & $0.31+/-0.03$ \\
\hline $8.92+1-2.4$ & $7.52+/-1.6$ & $2.93+/-1.23$ & $5.48+/-4.83$ & $4.46+/-2.93$ & $3.72+/-1.58$ & $0.01+/-0.01$ & $0.02+/-0.01$ & $0.02+/-0.01$ & $0.01+/-0.01$ \\
\hline $1010.99+/-671.64$ & $598.94+/-47.43$ & $483.2+/-437.71$ & $804.82+/-771.55$ & $333.62+/-282.57$ & $316.36+/-246.99$ & $164.47+/-73$ & $161.27+/-36.7$ & $111.69+/-57.94$ & $114.19+/-29.13$ \\
\hline $0.01+1-0$ & $0.02+/-0$ & $0.02+/-0$ & $0.01+/-0$ & $0.01+/-0$ & $0.01+/-0$ & $0+/-0$ & $0+/-0$ & $0+/-0$ & $0+/-0$ \\
\hline $1237.68+/-200.91$ & $1427.1+/-88.21$ & $1533.87+/-308.74$ & $1197.11+/-205.93$ & $1249.74+/-50.5$ & $1459.44+/-248.47$ & $44.27+/-39.35$ & $84.29+/-89.64$ & $32.39+/-47.24$ & $10.57+/-18.31$ \\
\hline $0.72+/-0.28$ & $0.42+/-0.02$ & $0.2+/-0.05$ & $0.36+/-0.2$ & $0.21+/-0.09$ & $0.19+/-0.07$ & $0+1-0$ & $0.01+/-0.01$ & $0.01+/-0$ & $0+/-0$ \\
\hline $747.94+/-57.13$ & $890.82+/-9.69$ & $1120.08+/-131.19$ & $709.2+/-171.36$ & $746.94+/-62.43$ & $902.99+/-212$ & $159.71+/-66.08$ & $149.65+/-44.42$ & $104.42+/-37.06$ & $151.23+/-66.11$ \\
\hline $13.71+/-1.2$ & $10.88+/-2.92$ & $9.47+/-0.91$ & $9.19+/-1.51$ & $6.42+/-2.28$ & $6.52+/-1.58$ & $0.13+/-0.07$ & $0.21+/-0.1$ & $0.16+/-0.03$ & $0.11+/-0.04$ \\
\hline $0.02+/-0$ & $0.02+/-0.01$ & $0.02+/-0$ & $0.02+/-0.01$ & $0.02+/-0.01$ & $0.02+1-0$ & $0+1-0$ & $0+/-0$ & $0+/-0$ & $0+1-0$ \\
\hline $3117.03+/-279.68$ & $3611.5+/-165.57$ & $4410.06+/-961.13$ & $3137.77+/-1111.01$ & $3239.95+/-53.66$ & $3355.63+/-664.39$ & $157.58+/-128.4$ & $155.63+/-61.6$ & $117.32+/-32.01$ & $140.82+/-69.59$ \\
\hline $2889.96+/-239.7$ & $3262.73+/-144.19$ & $4027.75+/-814.98$ & $2941.75+/-1020.9$ & $2962.14+/-108.16$ & $3120.5+/-580.25$ & $151.68+/-59.08$ & $151.94+/-61.36$ & $131.8+/-59.18$ & $135.62+/-62.76$ \\
\hline $3093.32+/-531.99$ & $2340.43+/-1380.29$ & $1677.52+/-333.29$ & $2290.17+/-485.44$ & $2345.07+/-743.54$ & $1701.04+/-555.57$ & $0+/-0$ & $0.53+/-0.92$ & $1.14+/-1.24$ & $0.77+/-1.34$ \\
\hline $2.19+/-0.51$ & $3.5+/-1.33$ & $3.33+/-0.48$ & $1.49+/-0.53$ & $1.97+/-0.34$ & $2.82+/-0.38$ & $0+1-0$ & $0.01+/-0$ & $0.01+/-0$ & $0+/-0$ \\
\hline $0.11+/-0.02$ & $0.1+/-0.03$ & $0.09+/-0.01$ & $0.09+/-0.01$ & $0.08+/-0.02$ & $0.08+/-0.02$ & $0+/-0$ & $0+/-0$ & $0+1-0$ & $0+1-0$ \\
\hline $5260.05+/-180.79$ & $5951.41+/-222.05$ & $6769.6+/-606.66$ & $5295.83+/-1086.18$ & $6209.91+/-206.59$ & $6530.56+/-524.3$ & $1036.49+/-295.91$ & $1235.69+/-383.19$ & $1042.04+/-256.38$ & $1231.58+/-769.61$ \\
\hline $28.97+/-4.23$ & $29.19+/-7.03$ & $28.74+/-4.16$ & $24.57+/-4$ & $26.58+/-5.69$ & $26.88+/-4.81$ & $12.71+/-1.22$ & $11.88+/-1.66$ & $11.83+/-1.93$ & $10.56+/-2.34$ \\
\hline $0.1+/-0.02$ & $0.14+/-0.05$ & $0.14+/-0.03$ & $0.09+/-0.02$ & $0.12+/-0.01$ & $0.14+/-0.02$ & $0+/-0$ & $0+/-0$ & $0+/-0$ & $0+1-0$ \\
\hline $225.52+/-53.41$ & $294.2+/-89.56$ & $320.85+/-29.79$ & $200.68+/-127.54$ & $238.91+/-69.09$ & $270.85+/-40.5$ & $92.78+/-30.67$ & $128.42+/-55.71$ & $142.85+/-52.31$ & $131.72+/-129.49$ \\
\hline $1166.54+/-382.79$ & $1362.73+/-365.68$ & $1121.22+/-524.94$ & $1303.75+/-259.1$ & $1538.44+/-49.96$ & $1104.14+/-438.61$ & $24.32+/-15.93$ & $27.1+/-8.54$ & $35.88+/-23.49$ & $31.66+/-20.82$ \\
\hline $2248.09+/-268.07$ & $3589.73+/-591.13$ & $3420.63+/-1031.65$ & $2645.43+/-645.74$ & $3956.86+/-835.27$ & $3734.54+/-603.03$ & $88.28+/-47.21$ & $96.11+/-34.41$ & $126+/-62.95$ & $100.63+/-53.79$ \\
\hline $146802.48+/-15855.25$ & $153754.09+/-19809.51$ & $149094.16+/-17113.16$ & $143323.63+/-13285.47$ & $137558.51+/-10982.71$ & $139608.15+/-15560.64$ & $1720.28+/-1417.48$ & $2164.38+/-1503.51$ & $1610.65+/-1371.28$ & $3057.66+/-861.93$ \\
\hline $7.66+/-2.64$ & $8.28+/-1.86$ & $7.39+/-1.69$ & $8.33+/-1.32$ & $6.3+/-2.05$ & $7.37+/-1.9$ & $0.2+/-0.02$ & $0.16+/-0.05$ & $0.19+/-0.09$ & $0.17+/-0.08$ \\
\hline $1.84+/-0.96$ & $1.99+/-0.96$ & $1.47+/-0.33$ & $1.45+/-0.85$ & $1.23+/-0.73$ & $1.4+/-0.58$ & $0.11+/-0.16$ & $0.01+/-0$ & $0.04+/-0.01$ & $0.02+/-0$ \\
\hline $119868.17+/-24876.06$ & $138350.65+/-33418.35$ & $144468.3+/-27287.21$ & $97714.24+/-11684.31$ & $114802.42+/-16415.29$ & $131700.57+/-22601.3$ & $2286.92+/-1926.89$ & $1137.46+\mid-42.95$ & $2066.1+/-352.81$ & $2058.09+/-709.71$ \\
\hline R2 13.5Bé NO MLF- & R2 13.5Bé N200 MLF- & R2 13.5Bé N400 MLF- & R2 12.5Bé NO MLF- & R2 12.5Bé N200 MLF- & 12.5Bé N400 M & & & & \\
\hline 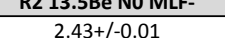 & K2 13.5Be NZU OVILF- & R2 13.JBe N400 UliLr- & 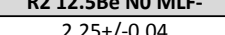 & $\frac{K 212.3 \mathrm{Be} \text { NLOU VILF- }}{2.3+-0.03}$ & 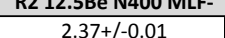 & & & & \\
\hline $\begin{array}{l}2.43+7-0.01 \\
2.69+/-0.08\end{array}$ & $2.57+/-0.03$ & $2.65+/-0.06$ & $2.54+/-0.11$ & $2.39+/-0.04$ & $2.34+/-0$ & & & & \\
\hline $0.61+/-0.53$ & $0.27+/-0.47$ & $0.25+/-0.44$ & $0.33+/-0.58$ & $0.93+/-0.08$ & $0.28+/-0.49$ & & & & \\
\hline $6.66+/-0.02$ & $6.46+/-0.11$ & $6.46+/-0.04$ & $6.39+/-0.02$ & $6.01+/-0.08$ & $6.04+/-0.03$ & & & & \\
\hline $0.2+/-0.06$ & $0.19+/-0.02$ & $0.23+/-0.04$ & $0.14+/-0.06$ & $0.15+/-0.01$ & $0.15+/-0.01$ & & & & \\
\hline $99.57+/-0.39$ & $99.89+/-0.42$ & $99.91+/-0.57$ & $91.05+/-0.72$ & $91.11+/-1.24$ & $92.31+/-0.31$ & & & & \\
\hline
\end{tabular}


bioRxiv preprint doi: https://doi.org/10.1101/2020.07.29.226142; this version posted July 30, 2020. The copyright holder for this preprint (which was not certified by peer review) is the author/funder. All rights reserved. No reuse allowed without permission.
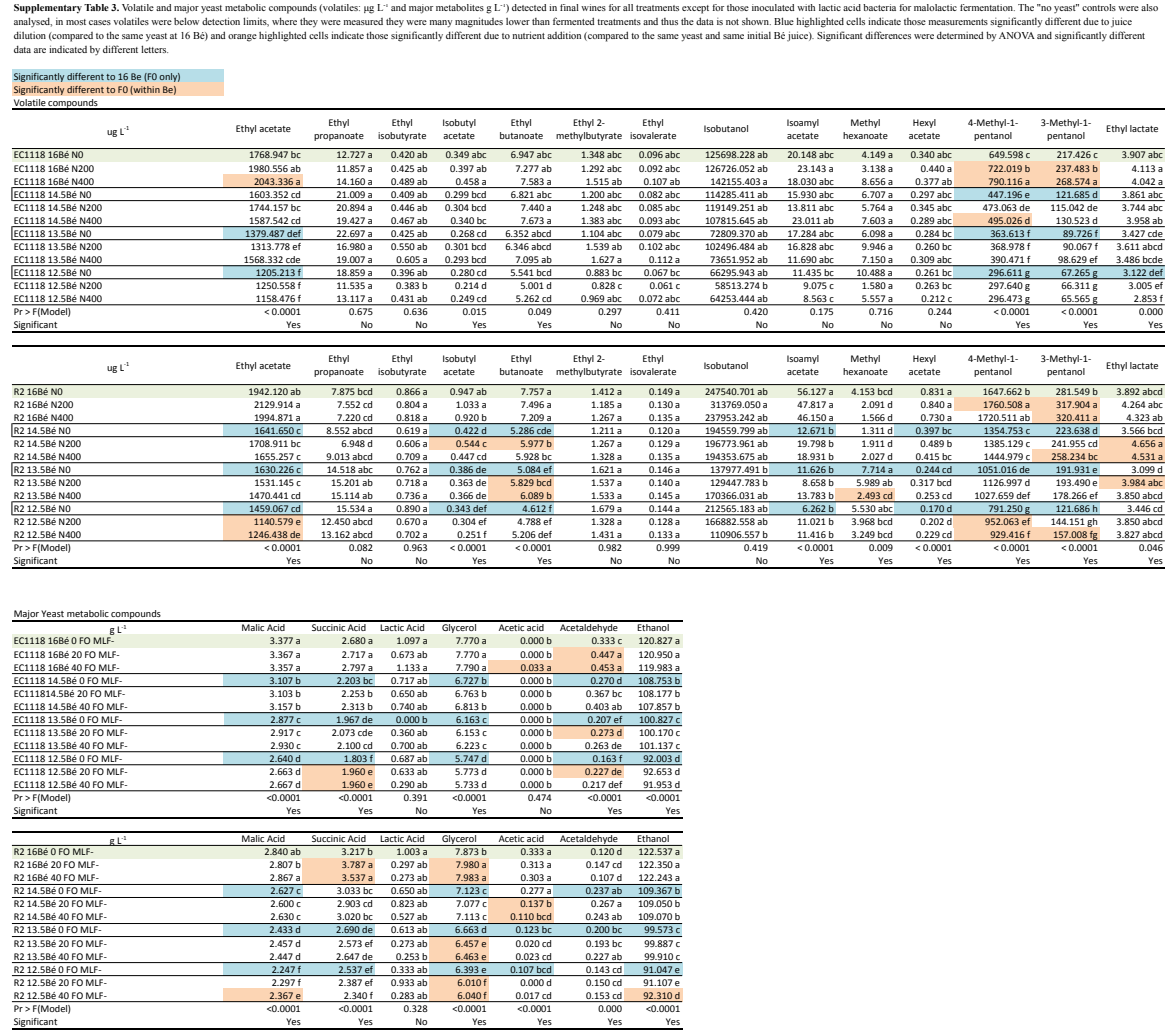
bioRxiv preprint doi: https://doi.org/10.1101/2020.07.29.226142; this version posted July 30, 2020. The copyright holder for this preprint (which was not certified by peer review) is the author/funder. All rights reserved. No reuse allowed without permission.

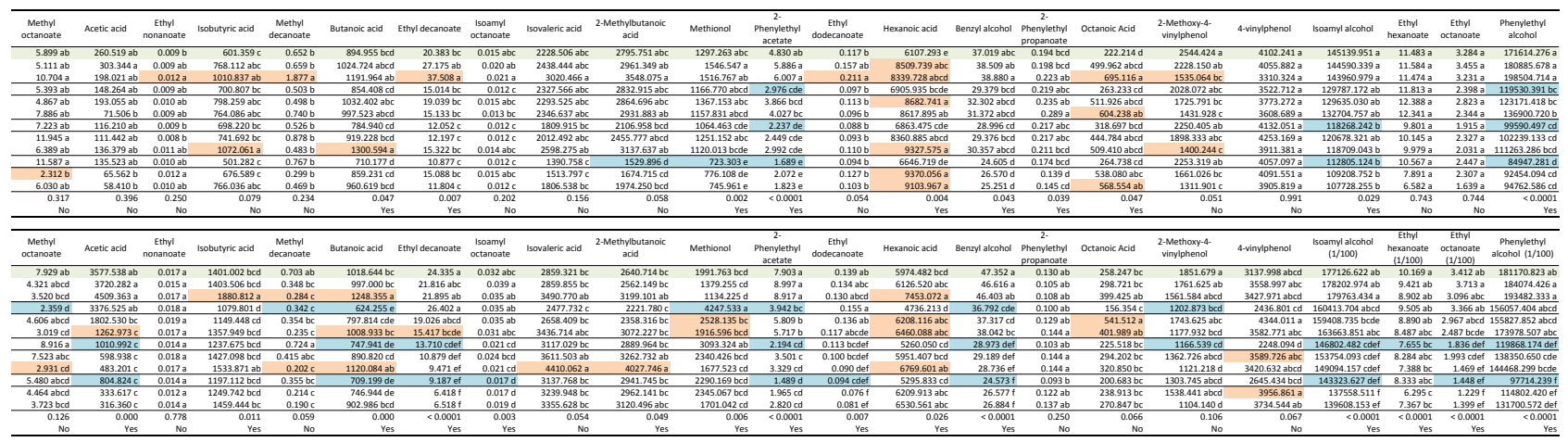


bioRxiv preprint doi: https://doi.org/10.1101/2020.07.29.226142; this version posted July 30, 2020. The copyright holder for this preprint (which was not certified by peer review) is the author/funder. All rights reserved. No reuse allowed without permission.

Supplementary Table 4. Ratios of significantly different compounds measured by HPLC. Ratios of compounds detected in wines made from diluted juices are in comparison to 16 Bé juices fermented by the same yeast, or in the case of where nutrient is added, to wines made from juices of the same Bé. Increased ratios are highlighted in green and decreased in pink. Results for wines made from 16 Bé juices with no nutrient addition are displayed as actual values $\left(\mathrm{g} \mathrm{L}^{-1}\right)+/-\mathrm{SD}$. Significant differences were determined by ANOVA.

\begin{tabular}{|c|c|c|c|c|c|c|}
\hline & Malic Acid & Succinic Acid & Lactic Acid & Glycerol & Acetaldehyde & Ethanol \\
\hline EC1118 16Bé 0 FO MLF- & $3.38+/-0.05$ & $2.68+/-0.11$ & $1.1+/-0.14$ & $7.77+/-0.01$ & $0.33+/-0.01$ & $120.83+/-0.29$ \\
\hline EC1118 16Bé 20 FO MLF- & & & & & 1.34 & \\
\hline EC1118 16Bé 40 FO MLF- & & & & & 1.36 & \\
\hline EC1118 14.5Bé 0 FO MLF- & 0.92 & 0.82 & & 0.87 & 0.81 & 0.90 \\
\hline \multicolumn{7}{|l|}{ EC111814.5Bé 20 FO MLF- } \\
\hline EC1118 13.5Bé 0 FO MLF- & 0.85 & 0.73 & 0.00 & 0.79 & 0.62 & 0.83 \\
\hline EC1118 13.5Bé 20 FO MLF- & & & & & 1.32 & \\
\hline \multicolumn{7}{|l|}{ EC1118 13.5Bé 40 FO MLF- } \\
\hline EC1118 12.5Bé 0 FO MLF- & 0.78 & 0.67 & & 0.74 & 0.49 & 0.76 \\
\hline EC1118 12.5Bé 20 FO MLF- & & 1.09 & & & 1.39 & \\
\hline EC1118 12.5Bé 40 FO MLF- & & 1.09 & & & & \\
\hline $\mathrm{Pr}>\mathrm{F}($ Model $)$ & $<0.0001$ & $<0.0001$ & 0.391 & $<0.0001$ & $<0.0001$ & $<0.0001$ \\
\hline \multirow[t]{2}{*}{ Significant } & Yes & Yes & No & Yes & Yes & Yes \\
\hline & Malic Acid & Succinic Acid & Lactic Acid & Glycerol & Acetaldehyde & Ethanol \\
\hline R2 16Bé 0 FO MLF- & $2.84+/-0.04$ & $3.22+/-0.03$ & $1+/-0.02$ & $7.87+/-0.04$ & $0.12+/-0.01$ & $122.54+/-0.27$ \\
\hline R2 16Bé 20 FO MLF- & & 1.18 & & 1.01 & & \\
\hline R2 16Bé 40 FO MLF- & & 1.10 & & 1.01 & & \\
\hline R2 14.5Bé 0 FO MLF- & 0.92 & & & 0.90 & 1.97 & 0.89 \\
\hline $\begin{array}{l}\text { R2 14.5Bé } 20 \text { FO MLF- } \\
\text { R2 14.5Bé } 40 \text { FO MLF- }\end{array}$ & & & & & & \\
\hline R2 13.5Bé 0 FO MLF- & 0.86 & 0.84 & & 0.85 & 1.67 & 0.81 \\
\hline R2 13.5Bé 20 FO MLF- & & & & 0.97 & & \\
\hline R2 13.5Bé 40 FO MLF- & & & & 0.97 & & \\
\hline R2 12.5Bé 0 FO MLF- & 0.79 & 0.79 & & 0.81 & & 0.74 \\
\hline R2 12.5Bé 20 FO MLF- & & & & 0.94 & & \\
\hline R2 12.5Bé 40 FO MLF- & 0.83 & & & 0.94 & & 1.01 \\
\hline Pr $>$ F(Model) & $<0.0001$ & $<0.0001$ & 0.328 & $<0.0001$ & 0.000 & $<0.0001$ \\
\hline Significant & Ys & Ys & No & Yes & Yes & Yes \\
\hline
\end{tabular}




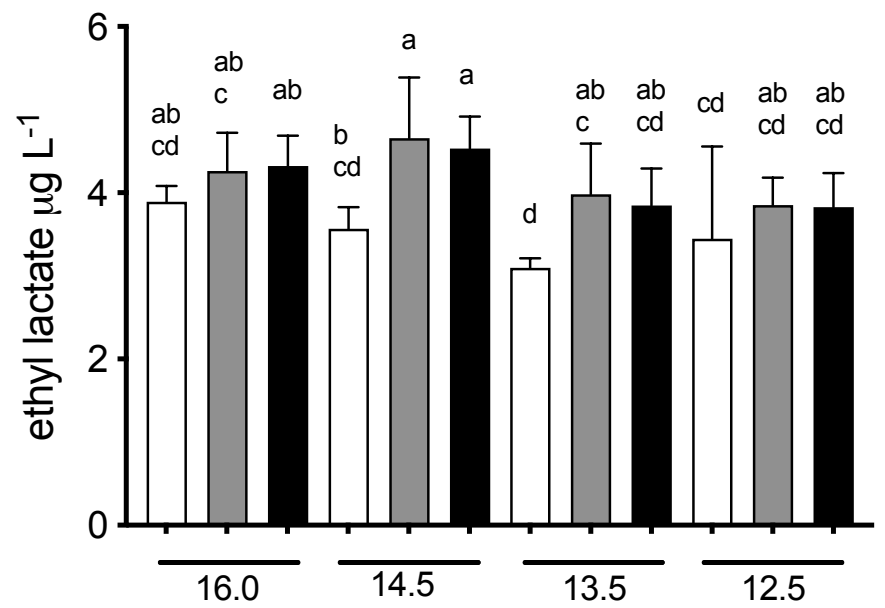

Supplementary Figure 1. Gardner et al. 